\title{
Expression of many developmentally regulated genes in Myxococcus depends on a sequence of cell interactions
}

\author{
Lee Kroos ${ }^{1}$ and Dale Kaiser \\ Department of Biochemistry, Stanford University School of Medicine, Stanford, California 94305 USA
}

Certain developmental mutants of Myxococcus xanthus can be complemented extracellularly by wild-type cells. These mutants behave as if they are defective in cell-cell interactions that are required for development. There may be several different interactions because the mutants belong to four extracellular complementation groups $(\mathrm{A}, \mathrm{B}, \mathrm{C}$, and $\mathrm{D})$. We report here that $\mathrm{B}^{-}$and $\mathrm{C}^{-}$mutations change the pattern of gene expression during Myxococcus development as detected by transcriptional fusions to lac Z mediated by Tn5 lac. The mutant $\mathrm{C}$ locus reduced or abolished developmental $\beta$-galactosidase expression from 15 lac fusions that normally begin to be expressed in wild-type cells after $6 \mathrm{hr}$ of development. Expression of these C-dependent lac fusions was restored to $\mathrm{C}^{-}$mutants by adding wild-type cells. The $\mathrm{C}^{-}$mutation did not affect the expression of 10 lac fusions that normally begin to be expressed before $6 \mathrm{hr}$ of development, indicating that the $C$-mediated cell-cell interaction is required beginning at about $6 \mathrm{hr}$ of development. Cells require the $B^{+}$function very early in development because a $B^{-}$mutation reduced or abolished developmental $\beta$-galactosidase expression from all 26 lac fusions tested, including some that normally begin to be expressed at the onset of development. In a $\mathrm{C}^{-}$ mutant and in a $B^{-}$mutant, some lac fusions responded with reduced $\beta$-galactosidase expression, whereas other fusions, which would normally begin $\beta$-galactosidase expression at about the same time during development, expressed no $\beta$-galactosidase, indicating that developmental genes within a given temporal class display different sensitivities to the absence of cell-cell interactions. Requirements for $\mathrm{B}^{+}$and $\mathrm{C}^{+}$function, as well as the previously described $A^{+}$function, appear to lie on the same developmental pathway.

[Key Words: Operon fusion; $\beta$-galactosidase; Myxobacteria; multicellular development; cell interactions]

Received June 15, 1987; revised version accepted August 19, 1987.

Myxococcus xanthus is a gram-negative soil bacterium that undergoes multicellular development and cellular differentiation (Rosenberg 1984). Upon starvation at a high cell density on a solid surface, cells move to aggregation centers where they construct a fruiting body. Within a nascent fruiting body, many cells lyse, while other cells differentiate to become resting, ovoid spores (Wireman and Dworkin 1975). About $10^{5}$ cells participate in constructing a fruiting body, and the process requires about $20 \mathrm{hr}$ from the removal of nutrient to the beginning of sporulation (Kroos et al. 1986). The number of heat-resistant spores in fruiting bodies then increases over a period of several days. How is the behavior of cells coordinated during this process of multicellular fruiting body development?

Cell-cell interactions have been implicated in the control of $M$. xanthus development by several experi-

1Present Address: Department of Cellular and Developmental Biology, Harvard University, Cambridge, Massachusetts 02138 USA

Nomenclature: The names $a s g, b s g, c s g$, and $d s g$ for the genes formerly called $s p o A, s p o B$, or $s s b$, spoC, and $s p o D$ were adopted at the 14th International Conference on the Biology of Myxobacteria. ments (Hagen et al. 1978; Shimkets and Dworkin 1981; LaRossa et al. 1983; Janssen and Dworkin 1985). Hagen et al. (1978) isolated conditional sporulation mutants (groups A, B, C, and D) which behave as if they are defective in cell-cell interactions that are required for normal development. The mutants cannot sporulate alone, but can be rescued for sporulation by co-development with wild-type cells or with cells of a different mutant group. The rescue does not involve genetic exchange between cells, but rather occurs extracellularly. All members of a group behave as if they are defective in the same cell-cell interaction. Each group appears to arrest development at a different stage, expressing earlier developmental markers and not later ones, as if each group of mutants were blocked at a different point on a developmental pathway (LaRossa et al. 1983; Kaiser et al. 1985). However, until recently, few markers that could be used to explore a developmental pathway were known for Myxococcus.

To identify new developmental markers, a transposable promoter-probe, called Tn5 lac, was constructed (Kroos and Kaiser 1984). Tn5 lac contains a promoterless lacZ gene inserted near one end of the transposon $\mathrm{Tn} 5$. 
When Tn5 lac transposes into a transcription unit in the correct orientation, it generates a transcriptional fusion to $l a c Z$, placing $\beta$-galactosidase expression under the control of the promoter for that transcription unit. Translation stop codons upstream of $l a c Z$ and in all three reading frames ensure that Tn5 lac forms transcriptional, and not translational, fusions. Among 2374 Tn5 lac insertions in Myxococcus, Kroos et al. (1986) identified 36 insertions that specifically increased $\beta$-galactosidase expression at some particular time during development. These characteristic times of expression ranged from minutes after starvation initiates development to $30 \mathrm{hr}$, when spores form. Restriction maps of Myxococcus DNA adjacent to the lac end of these Tn5 lac insertions indicated that at least 29 of them detect different transcription units (Kroos et al. 1986). Although these 36 lac fusions were formed by insertion of Tn5 lac into transcription units whose activity rises during development, only seven of these insertions ( $\Omega 4408, \Omega 4414, \Omega 4425, \Omega 4427, \Omega 4442, \Omega 4473, \Omega 4491$ ) cause detectible developmental abnormalities (Kroos et al. 1986). A description of the developmental phenotypes of these mutant insertion strains will be published separately. The lac fusion strains provide 29 new markers of Myxococcus development.

Kuspa et al. (1986) used the set of lac fusions generated by Tn5 lac to examine extracellular complementation of group A mutants. Each of two (unlinked) A- mutations greatly reduced developmental $\beta$-galactosidase expression from 18 of 21 Tn5 lac insertions tested. The earliest A-dependent Tn5 lac insertion normally begins $\beta$-galactosidase expression at $1.5 \mathrm{hr}$ of development, indicating an early developmental defect in $\mathrm{A}^{-}$mutants. Expression of the remaining three Tn5 lac insertions was unaffected by either of the $\mathrm{A}^{-}$mutations and these three insertions normally begin $\beta$-galactosidase expression at or before $5 \mathrm{hr}$ of development. When wild-type cells were added to $\mathrm{A}^{-}$mutants that contain $\mathrm{A}$-dependent Tn5 lac insertions and the mixtures were allowed to develop, an approximately normal pattern of developmental $\beta$-galactosidase expression was restored to the $\mathrm{A}^{-}$mutants. The rescue of $\beta$-galactosidase expression from an $\mathrm{A}$-dependent Tn5 lac insertion in $\mathrm{A}^{-}$mutant cells formed the basis of an assay that detects substances released by wild-type cells, but not by $\mathrm{A}^{-}$cells, $1-2 \mathrm{hr}$ after development is initiated. The results suggest that group A mutants fail to synthesize or to release adequate amounts of an extracellular signal that is required early for proper developmental gene expression and for the completion of fruiting body development.

To define more clearly the role of cell-cell interactions in the regulation of Myxococcus development, we have examined the effects of a $\mathrm{B}^{-}$mutation and a $\mathrm{C}^{-}$ mutation on $\beta$-galactosidase expression from the same set of developmentally regulated lac fusions that had been examined with the $\mathrm{A}^{-}$mutants. The patterns of expression indicate that $\mathrm{B}^{+}$, like $\mathrm{A}^{+}$, is required very early in Myxococcus development, while $\mathrm{C}^{+}$is required later. The results also suggest that $\mathrm{A}^{+}, \mathrm{B}^{+}$, and $\mathrm{C}^{+}$act on the same regulatory pathway.

\section{Results}

Effects of a $\mathrm{C}^{-}$mutation on developmental gene expression

All of the mutations that belong to group $\mathrm{C}$ are clustered in the spoC region of the Myxococcus genome (Shimkets et al. 1983). Introduction of this locus, now called csg for C signal, as a $1.6-\mathrm{kbp}$ fragment of DNA from $c s g^{+}$ strains can rescue all existing $\mathrm{C}^{-}$mutants, and Tn5 insertions in the $1.6-\mathrm{kbp}$ fragment cause $\mathrm{C}^{-}$mutations when introduced into the $M$. xanthus chromosome as gene replacements (Shimkets and Asher 1987). We used the insertion mutation csg-205 (Shimkets and Asher 1987) to construct $\mathrm{C}^{-}$derivatives of lacZ fusion strains to investigate how the loss of $\mathrm{C}^{+}$function would affect the expression of developmentally regulated genes (Table 1 and Materials and methods).

The $\mathrm{C}^{-}$derivatives of all lacZ fusion strains, except the one noted in the legend to Table 1 , showed a typical $\mathrm{C}^{-}$phenotype; Figure 1 shows that the developmentally normal $\mathrm{C}^{+}$lac fusion strains aggregate into compact translucent mounds by $12 \mathrm{hr}$, while their $\mathrm{C}^{-}$derivatives form larger, less compact translucent mounds and ridges beginning at about $18 \mathrm{hr}$. Also, by $12 \mathrm{hr}$, wild-type lac fusion strains form the parallel ridges of cells termed "ripples" (Shimkets and Kaiser 1982) in the areas between mounds, whereas their $\mathrm{C}^{-}$derivatives fail to form ripples. During normal Myococcus development more than half the cells lyse (Wireman and Dworkin 1975). Figure 2 shows that whereas the number of rod-shaped cells falls 10-fold between 12 and $48 \mathrm{hr}$ in the $\mathrm{C}^{+}$strain, in the corresponding $\mathrm{C}^{-}$strains the number stays roughly constant. In $\mathrm{C}^{+}$strains the translucent mounds begin to darken by $24 \mathrm{hr}$ as sporulation begins, and eventually $2-4 \%$ of the number of cells initially plated become sonication- and heat-resistant viable spores (Table 2); however the $\mathrm{C}^{-}$derivatives of the same lacZ fusion strains sporulate at much reduced levels. Figure 1 shows that the large translucent mounds which the $\mathrm{C}^{-}$strains had formed by 18-24 hr later begin to spread out, lose their definition, and eventually disappear-apparently as the result of cell movement. Thus, the $\mathrm{C}^{-}$cells not only fail to lyse and to sporulate, but also are motile at a time when $\mathrm{C}^{+}$cells have ceased to move.

To investigate the effect of the $\mathrm{C}^{-}$insertion mutation on expression of developmentally regulated genes, $\beta$-galactosidase was measured in a series of fusion strains. The $\mathrm{C}^{-}$Tn5 lac derivatives and their wild-type Tn5 lac parents were each plated on starvation agar to initiate development. After 6, 12, 18, 24, 36, 48, and $72 \mathrm{hr}$ of incubation, each strain was scraped from the agar, suspended, sonicated to break open the cells, and assayed for $\beta$-galactosidase activity and total protein. The profiles of $\beta$-galactosidase specific activity versus time of development for $\mathrm{C}^{-}$and $\mathrm{C}^{+}$versions of 26 different strains with developmentally regulated lac fusions are summarized in Table 3.

Comparison of $\beta$-galactosidase expression in $\mathrm{C}^{-}$and $\mathrm{C}^{+}$strains revealed three different responses to the $\mathrm{C}^{-}$ mutation: $\beta$-galactosidase expression was either 
Table 1. Tn5 lac insertion strains

\begin{tabular}{|c|c|c|c|}
\hline$\Omega$ & $\begin{array}{l}\text { Wild-type } \\
\text { DK1622 }\end{array}$ & $\mathrm{C}^{-}$derivative & $\mathbf{B}^{-}$derivative \\
\hline 4273 & DK4290 & DK5218 & DK5230 \\
\hline 4400 & DK4292 & DK5247 & DK5258 \\
\hline 4401 & DK4293 & DK5229 & DK5241 \\
\hline 4403 & DK4368 & DK5270 & - \\
\hline 4406 & DK4294 & DK5227 & DK5239 \\
\hline 4408 & DK4300 & DK5219 & DK5231 \\
\hline 4411 & DK5200 & DK5222 & DK5234 \\
\hline 4414 & DK5279b & DK5287 & DK5286 \\
\hline 4427 & DK5280 & DK5289 & DK5288 \\
\hline 4435 & DK5204 & DK5253 & - \\
\hline 4445 & DK4296 & DK5248 & DK5259 \\
\hline 4455 & DK5206 & DK5223 & DK5235 \\
\hline 4457 & DK5207 & DK5221 & DK5233 \\
\hline 4459 & DK4299 & DK5251 & DK5265 \\
\hline 4469 & DK4469 & DK5224 & DK5236 \\
\hline 4473 & DK4473 & DK5250 & - \\
\hline 4474 & DK4474 & DK5249 & DK5267 \\
\hline 4480 & DK4480 & - & DK5266 \\
\hline 4491 & DK5285 & DK5296c & DK5295 \\
\hline 4492 & DK4492 & DK5271 & DK5268 \\
\hline 4494 & DK4494 & DK5244 & DK5255 \\
\hline 4497 & DK4497 & DK5252 & - \\
\hline 4499 & DK4499 & DK5246 & DK5257 \\
\hline 4500 & DK4500 & - & DK5264 \\
\hline 4506 & DK4506 & DK5272 & DK5269 \\
\hline 4514 & DK4514 & DK5225 & DK5237 \\
\hline 4521 & DK4521 & DK5220 & DK5232 \\
\hline 4529 & DK4529 & DK5228 & DK5240 \\
\hline 4530 & DK4530 & - & DK5260 \\
\hline 4531 & DK4531 & - & DK5261 \\
\hline
\end{tabular}

The site of $\operatorname{Tn} 5$ lac insertion is designated by $\Omega$ followed by a number. The set of Tn5 Iac insertions has been described previously (Kroos et al. 1986). In particular, $\Omega 4273$ is a Tn5 lac insertion in tps, the gene that encodes spore coat protein $\mathrm{S}$.

a The wild-type strain that provides the genetic background for all these derivatives is DK1622, which is fully motile and fruiting competent (Kaiser 1979).

b These strains were constructed by transduction of the Tn 5 lac insertion from a variant of DK1622 that was not fully motile into fully motile DK1622 using Mx8 clp2 with selection for $\mathrm{Km}^{\mathrm{r}}$ as described (Kroos et al. 1986).

${ }^{c}$ The $\mathrm{C}^{-}$derivative containing Tn5 lac $\Omega 4491$ did not show a typical $\mathrm{C}^{-}$phenotype. (See text for typical $\mathrm{C}^{-}$phenotype.) Rather, it showed the aggregation defect seen for Tn5 lac $\Omega 4491$ in a wild-type background (Kroos et al. 1986): the aggregates are larger in number and smaller in size than normal and they appear 6-12 hours late. The $\mathrm{B}^{-}$derivative of Tn5 lac $\Omega 4491$ did show a typical $\mathrm{B}^{-}$phenotype which is described in the text.

"normal", "reduced", or "abolished" compared to the corresponding $\mathrm{C}^{+}$strain. The 10 strains presented in the upper section of Table 3 illustrate the first response. The lac fusions carried by these strains are expressed in $\mathrm{C}^{+}$ cells beginning at $0-5 \mathrm{hr}$ of development and are expressed very similarly in the $\mathrm{C}^{-}$mutant and the $\mathrm{C}^{+}$ parent (Table 3 and Fig. 3a,b). Some fusion strains included in this class, like $\Omega 4494$ shown in Figure $3 \mathrm{~b}$, expressed $\beta$-galactosidase in the $\mathrm{C}^{-}$derivative parallel to that in the wild-type strain to the $\mathrm{C}^{+}$peak, then, while specific activity falls in the $\mathrm{C}^{+}$strain, it continues to increase in the $\mathrm{C}^{-}$strain. Strains containing $\Omega 4457$,
$\Omega 4521, \Omega 4455, \Omega 4411, \Omega 4469, \Omega 4273$ also behave this way (Table 3 ). Lysis and sporulation probably account for the decreased $\beta$-galactosidase specific activity observed for wild-type strains late in development (Kroos et al. 1986). Lysis would expose $\beta$-galactosidase to proteases, and sporulation would sequester $\beta$-galactosidase in sonication-resistant spores. Since the $C^{-}$mutants fail to lyse or to sporulate, $\beta$-galactosidase can continue to be synthesized in the mutants, at a time when in the wild-type it is either released to extracellular breakdown by lysis or sequestered in spores.

Reduced expression was the second response to a $\mathrm{C}^{-}$ mutation, and it was observed in eight lac fusions that begin to express $\beta$-galactosidase before $16 \mathrm{hr}$ of development in the corresponding $\mathrm{C}^{+}$strains (Table 3 , middle section). In general, the fusions in this class increase $\beta$ galactosidase activity at a lower rate in $\mathrm{C}^{-}$than in $\mathrm{C}^{+}$ strains. Two insertion strains giving this response, $\Omega 4514$ (shown in Fig. 3c) and $\Omega 4400$ (Table 3), reach a lower $\beta$-galactosidase specific activity in the $\mathrm{C}^{-}$derivative at the time of peak expression in wild-type (compare columns 4 and 5 in Table 3 ). However at later times the $\mathrm{C}^{-}$derivative did reach a level of activity similar to the wild-type peak. Figure $3 \mathrm{~d}$ shows that the $\mathrm{C}^{+}$strain with lac fusion $\Omega 4427$ begins to express $\beta$-galactosidase at 0 hr. The corresponding $\mathrm{C}^{-}$strain responds with reduced expression: The $\beta$-galactosidase specific activity in the $\mathrm{C}^{-}$and $\mathrm{C}^{+}$strains was the same at $6 \mathrm{hr}$ of development, but subsequent activity was lower in the $\mathrm{C}^{-}$derivative, reaching $57 \%$ of the $\mathrm{C}^{+}$peak activity. For the remaining five lac fusion strains with reduced expression, $\beta$-galactosidase specific activity was less at each time in the $\mathrm{C}^{-}$ derivative than in the corresponding $\mathrm{C}^{+}$strain, reaching $27-53 \%$ of the wild-type peak activity $(\Omega 4474$, Fig. 3e, also $\Omega 4499$, $\Omega 4414, \Omega 4473$, and $\Omega 4492$, Table 3 ). Although the $\mathrm{C}^{-}$mutation reduced the level of $\beta$-galactosidase expression from these eight lac fusion strains, it did not appreciably change the time that $\beta$-galactosidase activity began to rise, as measured by their "expression time" (these data are not included in Table 3).

A third response to the $\mathrm{C}^{-}$mutation was the "abolition" of $\beta$-galactosidase activity, described in the bottom section of Table 3 . Eight lac fusion strains, whose $\mathrm{C}^{+}$ counterparts would have begun expression at 11-30 hr of development gave this response. For all but two of the $\mathrm{C}^{+}$derivatives of these fusion strains, $\beta$-galactosidase expression increased before cells became sonication resistant, but maximum specific activity was observed only if spores were disrupted. See for example $\Omega 4506$ in Figure $3 f_{\text {; }}$ fusion strains $\Omega 4406, \Omega 4459, \Omega 4529, \Omega 4435$, and $\Omega 4497$ (Table 3 ) were similar. The remaining two fusion strains in which the $\mathrm{C}^{-}$mutation abolished expression are $\Omega 4403$, for which maximum $\beta$-galactosidase specific activity was detected in the wild-type strain without spore disruption, and $\Omega 4401$ for which $\beta$-galactosidase expression increased in the wild-type strain only after cells became sonication resistant.

\section{Extracellular complementation of $\mathrm{C}^{-}$mutants}

Normal morphological development of $\mathrm{C}^{-}$mutants can be "rescued" by adding wild-type cells in equal propor- 


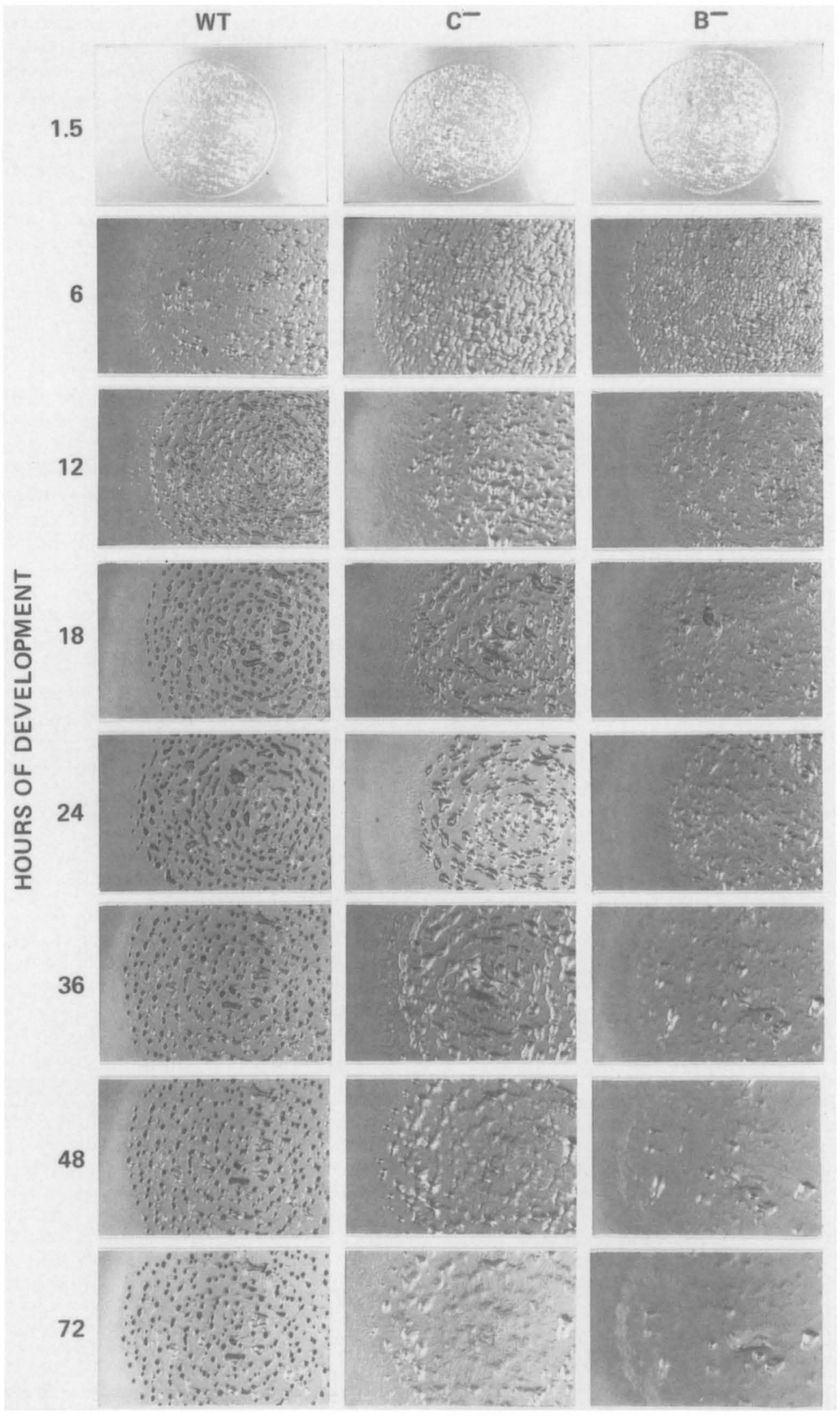

Figure 1. Morphological development of wild-type and mutants. Wild-type (wt), $\mathrm{C}^{-}$, and $\mathrm{B}^{-}$strains (all containing Tn5 lac $\Omega 4499$, which does not affect development) were spotted on starvation (TPM) agar as described in Materials and methods. Photomicrographs were taken at $4.2 \times$ magnification after the indicated number of hours at $32^{\circ} \mathrm{C}$, except the $t=1.5$ photo was taken at $2.5 \times$ magnification to show an entire spot. 


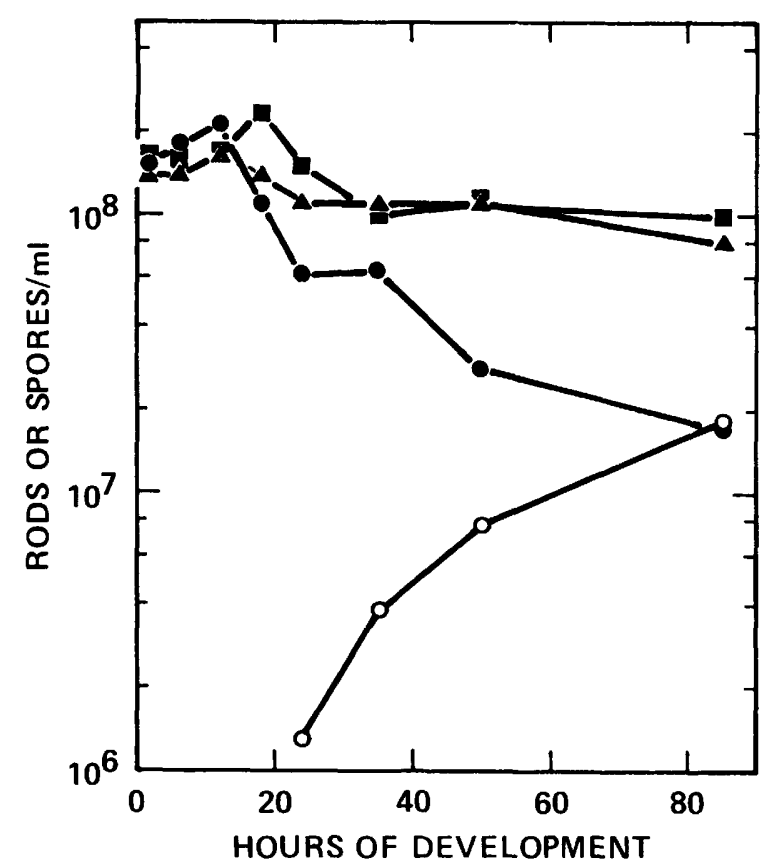

Figure 2. Lysis and sporulation of wild-type, $\mathrm{C}^{-}$, and $\mathrm{B}^{-}$ strains. Strains were spotted on starvation (TPM) agar in 24well tissue-culture plates, and the number of rods and spores in samples harvested at various times of development was determined by counting in a Petroff-Hausser chamber as described in Materials and methods. Points are the average for two strains to reduce strain to strain variation. Rods $(O)$ and spores $(O)$ were observed for wild-type strains DK1622 and DK5207. Only rods were observed for $\mathrm{C}^{-}$strains (A) DK5221 and DK5246 and Bstrains () DK5233 and DK5257. tion and plating on starvation agar. In these mixtures the $\mathrm{C}^{-}$cells sporulate at frequencies close to wild type (Table 2), implying an efficient rescue of the mutants' capacity to develop. Without added wild-type cells, the (background) sporulation levels of two $\mathrm{C}^{-}$lac fusion derivatives (DK5246 and DK5221) and the $\mathrm{C}^{-}$strain (LS253) from which they were constructed are $0.03 \%$ or less that of wild type (Table 2).

To what extent does extracellular complementation restore the normal pattern of developmental gene expression to $\mathrm{C}^{-}$mutants? Six different lac fusion strains were examined, three of whose expression was reduced in the $\mathrm{C}^{-}$derivative and three of whose expression was abolished in the $\mathrm{C}^{-}$derivative. Each $\mathrm{C}^{-}$lac fusion strain was mixed with an equal number of wild-type cells (DK1622, which does not produce $\beta$-galactosidase) and the mixture was plated for development and subsequent $\beta$-galactosidase measurements. The data reported in Table 4 show that $\beta$-galactosidase expression was restored with approximately correct timing and amount to all six $\mathrm{C}^{-}$lac fusion strains by mixing them with wildtype cells. Figure 4 shows examples of the $\beta$-galactosidase specific activity profiles obtained in these extracellular complementation experiments for two Tn5 lac insertion strains: $\Omega 4499$, whose expression is reduced by $\mathrm{C}^{-}$and $\Omega 4435$, whose expression is abolished by $\mathrm{C}^{-}$.

The earliest reduction of developmental gene expression by the $\mathrm{C}^{-}$mutation was observed at $6 \mathrm{hr}$ : see $\Omega 4427, \Omega 4400$, and $\Omega 4499$ in Table 3 . Since expression from $\Omega 4499$ in a $C^{-}$mutant was restored to nearly wildtype levels between 6 and $12 \mathrm{hr}$ of development in the mixture with wild-type cells (Fig. 4a), the $\mathrm{C}^{-}$mutation

Table 2. Sporulation of $C^{-}$and $B^{-}$mutants

\begin{tabular}{|c|c|c|c|c|c|c|}
\hline \multirow[b]{2}{*}{ Strain } & \multirow[b]{2}{*}{ Genotype } & \multicolumn{2}{|c|}{ Sporulation $^{\mathbf{a}}$} & \multicolumn{3}{|c|}{ Extracellular complementation ${ }^{a}$} \\
\hline & & spores $/ \mathrm{ml}$ & percent & red spores $/ \mathrm{ml}$ & yellow spores $/ \mathrm{ml}$ & percent $w^{c}$ \\
\hline DK1622 & wild-type & $2 \times 10^{6}$ & $(100)$ & $7 \times 10^{6}$ & $1 \times 10^{6 b}$ & $\{100\}$ \\
\hline DK4499 & Tn5 lac $\Omega 4499$ & $4 \times 10^{6}$ & 200 & $1 \times 10^{7}$ & $1 \times 10^{6}$ & 100 \\
\hline DK5207 & Tn5 lac $\Omega 4457$ & $2 \times 10^{6}$ & 100 & $1 \times 10^{7}$ & $5 \times 10^{5}$ & 50 \\
\hline LS523 & $\mathrm{C}^{-}$ & 300 & .015 & $7 \times 10^{6}$ & $2 \times 10^{6}$ & 200 \\
\hline DK5246 & $\mathrm{C}^{-}, \operatorname{Tn} 5$ lac $\Omega 4499$ & 20 & .001 & $9 \times 10^{6}$ & $1 \times 10^{6}$ & 60 \\
\hline DK5221 & $\mathrm{C}^{-}, \operatorname{Tn} 5$ lac $\Omega 4457$ & 600 & .030 & $7 \times 10^{6}$ & $2 \times 10^{6}$ & 200 \\
\hline M380 & $\mathrm{B}^{-}$ & $<10$ & $<.0005$ & 900 & 20 & .002 \\
\hline DK5257 & $\mathrm{B}^{-}, \operatorname{Tn} 5$ lac $\Omega 4499$ & $<10$ & $<.0005$ & 700 & $<2$ & $<.0002$ \\
\hline DK5233 & $\mathrm{B}^{-}, \operatorname{Tn} 5$ lac $\Omega 4457$ & $<10$ & $<.0005$ & 300 & $<10$ & $<.001$ \\
\hline
\end{tabular}

a Sporulation tests were performed as described in Materials and methods. In the extracellular complementation tests approximately 5 $\times 10^{7}$ cells of the $\mathrm{B}^{+} \mathrm{C}^{+}$red strain DK4696 were mixed with an equal number of cells of the yellow strains listed in the first column and the mixtures were plated for development as described in Materials and methods. The numbers of heat- and sonication-resistant spores formed by 3 days that were able to germinate and produce either red or yellow colonies are presented in the table. Some spores germinated to produce tan colonies in which case their origin as "red" or "yellow" was deduced from their drug resistance and Lac phenotypes as described in Materials and methods. In general, tan colonies arose from the red strain at a frequency of $1-3 \%$ presumably due to reversion of the red-2 mutation in DK4696. Like DK4696 these strains were $\mathrm{Km}^{\mathrm{r}}$ and Lac ${ }^{-}$during growth. In mixtures with B- strains the overall survival is low and tan colonies arise from 14-33\% of the surviving "Red" spores. Tan colonies arise from the yellow strains by phase variation (Burchard et al. 1977). These tan colonies were $\mathrm{Km}^{\mathrm{r}}$ and $\mathrm{Lac}^{+}$in the case of Tn5 lac-containing yellow strains or $\mathrm{Km}^{\mathrm{s}}$ and $\mathrm{Lac}^{-}$in the case of yellow strains that do not contain $\mathrm{Tn} 5$ lac. Since the origin of tan strains could be deduced unambiguously from their drug resistance and Lac phenotypes, they are included in the "Red" and "Yellow" totals.

b The number of spores arising from yellow strains in the extracellular complementation test is expected to be half the number in the sporulation test because the total number of input cells is held constant between sporulation and complementation. Equal numbers of red DK4696 cells and yellow cells are mixed in the extracellular complementation test.

c Yellow spores as percent of the number produced by DK1622 alone. 
can be complemented extracellularly at the time the $\mathrm{C}^{-}$ defect is first evident. As shown in Figure 4a, complementation restores the $\mathrm{C}^{+}$pattern of developmental gene expression to $\mathrm{C}^{-}$mutants. The fact that it was necessary to disrupt spores to detect the maximum $\beta$-galactosidase specific activity in mixtures of wild-type cells with $\mathrm{C}^{-}$Tn5 lac derivatives containing $\Omega 4435$ and $\Omega 4401$ (Fig. 4 b and Table 4 ) reveals a $C^{+}$pattern of $\beta$-galactosidase expression for these two $\mathrm{C}^{-}$strains as well. Furthermore, rescued developmental $\beta$-galactosidase expression from $\Omega 4401$ in $\mathrm{C}^{-}$cells is observed only after the spores have become sonication resistant, which parallels the expression of $\Omega 4401$ in $\mathrm{C}^{+}$cells.

\section{Effects of a $\mathrm{B}^{-}$mutation on developmental gene expression.}

The B group of conditional sporulation mutants is genetically heterogeneous; however, at least three of the B mutants described by Hagen et al. (1978) map to the same locus (Kuner 1980; Y. Cheng, unpubl.). The ssbA330 allele, now called bsgA330 for B signal, an insertion near the middle of the locus previously shown to

Table 3. Effects of ' $C^{-}$mutation on developmental gene expression

\begin{tabular}{|c|c|c|c|c|c|c|}
\hline$\Omega$ & $\begin{array}{l}\text { Expression } \\
\text { time in } \\
\text { wild-type } \\
(\mathrm{hr})^{\mathrm{a}}\end{array}$ & $\begin{array}{l}\text { Wild- } \\
\text { type } \\
\text { veg. } \\
\text { S.A. }\end{array}$ & $\begin{array}{l}\text { S.A. at } \\
\text { wild-type } \\
\text { peakc }^{c}\end{array}$ & $\begin{array}{l}\text { S.A. in mutant } \\
\text { at time of } \\
\text { wild-type } \\
\text { peak }^{\text {d }}\end{array}$ & $\begin{array}{l}\text { S.A. at } \\
\text { mutant } \\
\text { peakc }^{c}\end{array}$ & $\begin{array}{l}\beta \text {-Galactosidase } \\
\text { expression } \\
\text { in } \mathrm{C}^{-\mathrm{e}}\end{array}$ \\
\hline 4491 & 0 & 4 & 22 & 18 & 18 & normal \\
\hline 4457 & 0 & 11 & 53 & 73 & 140 & normal \\
\hline 4408 & 1 & 12 & 50 & 42 & 46 & normal \\
\hline 4521 & 2 & 13 & 150 & 270 & 300 & normal \\
\hline 4494 & 2 & 24 & 160 & 140 & 210 & normal \\
\hline 4455 & 3 & 46 & 520 & 560 & 700 & normal \\
\hline 4445 & 4 & 27 & 1700 & 1200 & 1200 & normal \\
\hline 4411 & 5 & 28 & 190 & 190 & 320 & normal \\
\hline 4469 & 5 & 100 & 530 & 640 & 930 & normal \\
\hline 4273 & 5 & 2 & 65 & 55 & 110 & normal \\
\hline 4427 & 0 & 9 & 69 & 34 & 39 & reduced \\
\hline 4400 & 6 & 2 & 240 & 110 & 220 & reduced \\
\hline 4499 & 6 & 6 & 94 & 23 & 25 & reduced \\
\hline 4514 & 9 & 10 & 290 & 200 & 280 & reduced \\
\hline 4414 & 10 & 23 & 1100 & 410 & 580 & reduced \\
\hline 4473 & 13 & 20 & 1300 & 570 & 570 & reduced \\
\hline 4474 & 15 & 4 & 150 & 20 & 58 & reduced \\
\hline 4492 & 16 & 7 & 190 & 75 & 75 & reduced \\
\hline 4406 & 11 & 3 & $220^{f}$ & 17 & 18 & abolished \\
\hline 4506 & 14 & 8 & $140^{f}$ & 18 & 18 & abolished \\
\hline 4403 & 15 & 4 & 190 & 10 & 12 & abolished \\
\hline 4459 & 18 & 8 & $220^{f}$ & 20 & 22 & abolished \\
\hline 4529 & 23 & 4 & $180^{\mathrm{f}}$ & 8 & 8 & abolished \\
\hline 4435 & 25 & 3 & $450^{f}$ & 6 & 6 & abolished \\
\hline 4497 & 30 & 6 & $140^{f}$ & 11 & 11 & abolished \\
\hline 4401 & 30 & 9 & $230^{f}$ & 10 & 11 & abolished \\
\hline
\end{tabular}

The site of $\operatorname{Tn} 5$ lac insertion is designated by $\Omega$ followed by a number.

a The "expression time" is an estimate of when $\beta$-galactosidase specific activity begins to increase during development (Kroos et al. 1986). The expression times and specific activities reported were obtained for wild-type and $\mathrm{C}^{-} \mathrm{Tn} 5$ lac strains spotted on starvation agar and harvested in parallel in the same experiment. The time course of $\beta$-galactosidase specific activity changes during development for wild-type Tn5 lac strains in these experiments were in agreement with those published previously (Kroos et al. 1986). Furthermore, time courses for wild-type and $\mathrm{C}^{-}$strains were repeated for 11 lac fusions in the table; all were found to be reproduced. b Vegetative values are the specific activity (S.A.) of $\beta$-galactosidase in $t=0$ samples (i.e., cells sedimented from growth medium, suspended in starvation buffer, and immediately frozen). The units of $\beta$-galactosidase specific activity are nmoles ONP/min $\cdot \mathrm{mg}$ protein.

${ }^{c}$ Values are the highest $\beta$-galactosidase specific activities measured for wild-type (column 4) and $C^{-}(\operatorname{column} 6)$ Tn5 lac strains during 72 -hr developmental time courses.

d Values are the specific activities of $\mathrm{C}^{-}$Tn5 lac derivatives at the time when maximum $\beta$-galactosidase specific activity was observed for the corresponding wild-type Tn5 lac strain.

e The effect of a $\mathrm{C}^{-}$mutation on developmental $\beta$-galactosidase expression from each $\mathrm{Tn} 5$ lac insertion is summarized in this column. "Normal" indicates $\beta$-galactosidase expression began at the same time and reached a similar or higher specific activity in the $C^{-}$Tn 5 lac derivative than in the wild-type Tn5 lac strain. "Reduced" indicates $\beta$-galactosidase expression began at the same time but increased less rapidly and/or reached a lower maximum in the $\mathrm{C}^{-}$mutant than in wild type (see text). "Abolished" indicates that no developmental expression occurred in the $\mathrm{C}^{-}$mutant.

${ }^{f}$ The maximum $\beta$-galactosidase specific activity was observed when the 72 -hr sample was sonicated with glass beads to disrupt spores. Sonication with glass beads did not change the $\beta$-galactosidase specific activities of 72 -hr samples of $\mathrm{C}^{-} \mathrm{Tn} 5$ lac derivatives, as expected, since these samples contain very few spores. 

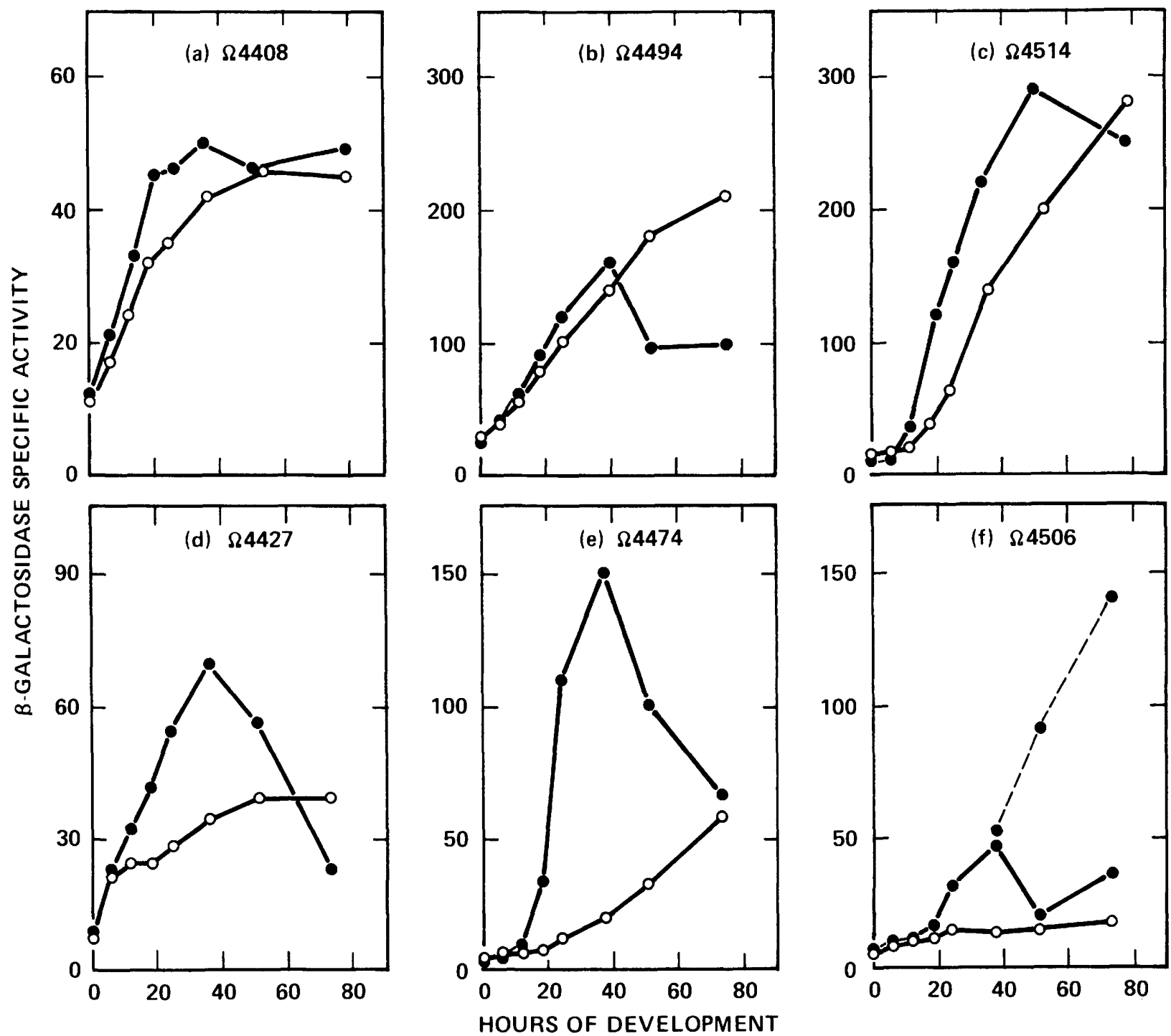

Figure 3. Effects of a $\mathrm{C}^{-}$mutation on expression of lac fusions in six different developmentally regulated transcription units. Wildtype and $\mathrm{C}^{-}$strains containing the same Tn5 lac insertion were constructed, plated for development, and harvested at various times for determination of $\beta$-galactosidase specific activity (nmole ONP/min-protein) as described in Materials and methods. Wild-type (O) and $C^{-}(O)$ strains containing Tn5 lac insertions $\Omega 4408(a), \Omega 4494(b), \Omega 4514(c), \Omega 4427(d), \Omega 4474(e)$, and $\Omega 4506(f)$ illustrate the different effects of the $\mathrm{C}^{-}$mutation on developmentally regulated expression of $\beta$-galactosidase. In $f$, the dashed line shows the specific activity obtained after samples were sonicated with glass beads to disrupt spores.

cause a $\mathrm{B}^{-}$phenotype (Gill and Cull 1986), was introduced into a series of lac fusion strains (Table 1 and Materials and methods). Each strain gave a $\mathrm{B}^{-}$phenotype. Figure 1 shows that these $\mathrm{B}^{-}$derivatives form loose aggregates that fail to progress to the translucent mound stage and that even the loose aggregates disappear after $24 \mathrm{hr}$. Like the $\mathrm{C}^{-}$strains, the $\mathrm{B}^{-}$strains failed to ripple and failed to lyse or to form appreciable numbers of spores (Fig. 2 and Table 2). However, since the $\mathrm{B}^{-}$strains failed to form the large translucent mounds and ridges seen for wild-type and for $\mathrm{C}^{-}$strains, the $\mathrm{B}^{-}$mutants show less extensive aggregation than the $\mathrm{C}^{-}$mutants.

Profiles of $\beta$-galactosidase specific activity versus time of development for the $\mathrm{B}^{-}$and wild-type derivatives of the 26 different developmentally regulated Tn5 lac insertion strains (Table 1) are summarized in Table 5. Two types of responses to the $\mathrm{B}^{-}$mutation are evident. "Reduced" expression of $\beta$-galactosidase was observed in the $\mathrm{B}^{-}$derivatives of 14 lac fusion strains that normally begin expression at $0-14 \mathrm{hr}$ of development (Table 5, upper section; and Fig. $5 \mathrm{a}-\mathrm{c}$ ). $\beta$-Galactosidase expression started in these $B^{-}$strains at about the same time as in $\mathrm{B}^{+}$strains. The average rate of $\beta$-galactosidase specific activity increase for $\mathrm{B}^{-}$derivatives was only $10-40 \%$ that observed for their $\mathrm{B}^{+}$parents, though eventually the specific activity of these $\mathrm{B}^{-}$strains reached $30-90 \%$ of the peak observed in their $\mathrm{B}^{+}$counterparts. While typically the $\beta$-galactosidase specific activity decreased in the $\mathrm{B}^{+}$strains between 36 and $72 \mathrm{hr}$ of development, it continued to increase or leveled off in the $\mathrm{B}^{-}$derivatives.

The second response to the $\mathrm{B}^{-}$mutation was the 
Table 4. Extracellular complementation of developmental gene expression from $\mathrm{C}^{-}$mutants

\begin{tabular}{|c|c|c|c|c|}
\hline$\Omega$ & $\begin{array}{l}\text { Expression } \\
\text { time in } \\
\text { wild-type } \\
(\mathrm{hr})^{\mathrm{a}}\end{array}$ & $\begin{array}{l}\text { Expression time } \\
\text { in mutant } \\
\text { mixed with } \\
\text { wild-type cells }\end{array}$ & $\begin{array}{l}\text { S.A. of } \\
\text { wild-type } \\
\text { at peak }\end{array}$ & $\begin{array}{l}\text { S.A. of mutant } \\
\text { mixed with } \\
\text { wild-type cells } \\
\text { at peak }\end{array}$ \\
\hline 4499 & 6 & 6 & 94 & 79 \\
\hline 4414 & 10 & 10 & 1100 & 680 \\
\hline 4492 & 16 & 16 & 190 & 170 \\
\hline 4403 & 15 & 15 & 190 & 180 \\
\hline 4435 & 25 & 25 & $450^{c}$ & $650^{c}$ \\
\hline 4401 & 30 & 30 & $230^{c}$ & $240^{c}$ \\
\hline
\end{tabular}

The site of $\operatorname{Tn} 5$ lac insertion is designated by $\Omega$ followed by a number.

a From Table 3.

$\mathrm{b}$ The expression times and peak specific activities are from the type of experiment shown in Fig. 4 in which equal numbers of $\mathrm{C}^{-}$Tn5 lac cells and wild-type cells (which do not contain Tn5 lac) are mixed and plated for development.

c The maximum $\beta$-galactosidase specific activity was observed when the 72 -hr sample was sonicated with glass beads to disrupt spores.

"abolition" of $\beta$-galactosidase activity, shown by $12 \operatorname{Tn} 5$ lac fusion strains listed in the lower section of Table 5. The $\mathrm{B}^{+}$derivatives of these fusion strains begin expression at 6-30 hr of development (Table 5 and Fig. $5 \mathrm{~d}$ ). Thus, in all 26 lac fusion strains tested, the $\mathrm{B}^{-}$mutation significantly reduced or abolished developmental $\beta$-galactosidase expression; no strain was unaffected by $B$. However, the $\mathrm{B}^{-}$mutation did not alter $\beta$-galactosidase expression levels during normal growth of the same 26 Tn5 lac insertion strains: The specific activities were comparable for $\mathrm{B}^{-}$and $\mathrm{B}^{+}$strains in the $t=0$ samples, which were prepared by sedimenting cells from growth medium, resuspending them in starvation buffer, and freezing them immediately, (see for example the $t=0$ points in Fig. $5 a-d$ ).

Using the standard conditions for extracellular complementation described in Materials and methods, we were unable to observe rescue of development of cells carrying the $\mathrm{B}^{-}$allele, bsgA330. Sonication-resistant spores were observed microscopically in the mixture after 3 days, but very few of them were able to germinate on plates after heat treatment (Table 2). After 6 days of codevelopment, the number of heat-resistant spores increased to $10^{6} / \mathrm{ml}$, but $<0.1 \%$ of them had arisen from $\mathrm{B}^{-}$cells in the mixture. The data of Table 2 show that the $\mathrm{B}^{-}$mutants also delayed and reduced sporulation of wild-type cells in the mixture. Neither was the expression of $\beta$-galactosidase restored to $\mathrm{B}^{-}$lac fusions during codevelopment with wild-type cells, although slight increases above the levels seen for $\mathrm{B}^{-} \mathrm{Tn} 5$ lac cells alone were observed (data not shown). On the other hand, Gill and Cull (1986) have reported rescue of a strain carrying bsgA330 using a different set of experimental conditions and Hagen et al. (1978) observed the rescue of two other B group mutations, B468 and B471. It seems likely that culture conditions which maximize rescue of $\mathrm{A}^{-}, \mathrm{B}^{-}$, or $\mathrm{C}^{-}$mutants are different because these functions are needed at different times in development: $1.5,0$, and 6 , hr respectively. To facilitate comparisons, we have chosen one standard set of complementation conditions;

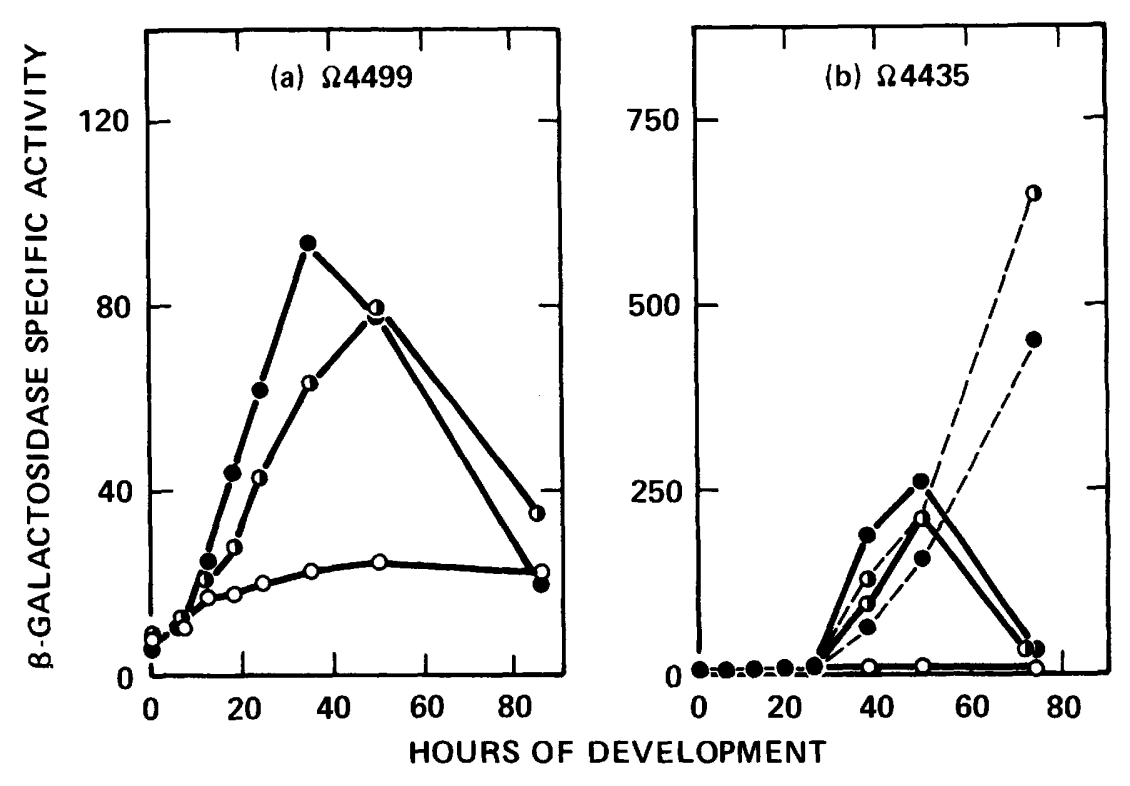

Figure 4. Extracellular complementation of developmental gene expression from $\mathrm{C}^{-} \mathrm{mu}-$ tants. Strains or mixtures were plated for development and harvested at various times for determination of $\beta$-galactosidase specific activity as described in Materials and methods. Profiles for the wild-type Tn5 lac strains (0) containing $\Omega 4499(a)$ and $\Omega 4435(b)$, their $\mathrm{C}^{-}$ Tn5 lac derivatives $(O)$, and mixtures containing an equal number of the $\mathrm{C}^{-} \mathrm{Tn} 5 \mathrm{lac}$ derivative and wild-type cells that do not produce $\beta$-galactosidase $(\boldsymbol{O})$ were all obtained in the same experiment. In $b$, all profiles are identical to the one shown for the wild-type Tn5 lac strain before $25 \mathrm{hr}$ of development and solid lines connect specific activities obtained after sonication (i.e., rods but not spores are disrupted), while dashed lines connect specific activities obtained after aliquots of the same samples were sonicated with glass beads, which disrupts spores as well as rods. 
Table 5. Effects of a $B^{-}$mutation on developmental gene expression

\begin{tabular}{|c|c|c|c|c|c|c|}
\hline$\Omega$ & $\begin{array}{l}\text { Expression } \\
\text { time in } \\
\text { wild-type } \\
(\mathrm{hr})^{\mathrm{a}}\end{array}$ & $\begin{array}{l}\text { Wild-type } \\
\text { veg. } \\
\text { S.A. }\end{array}$ & $\begin{array}{l}\text { S.A. at } \\
\text { wild-type } \\
\text { peak }^{c}\end{array}$ & $\begin{array}{l}\text { S.A. in mutant } \\
\text { at time of } \\
\text { wild-type } \\
\text { peak }^{\text {d }}\end{array}$ & $\begin{array}{l}\text { S.A. at } \\
\text { mutant } \\
\text { peakc }^{\text {c }}\end{array}$ & $\begin{array}{l}\beta \text {-galactosidase } \\
\text { expression } \\
\text { in } \mathrm{B}^{-} \\
\text {mutant }\end{array}$ \\
\hline 4491 & 0 & 4 & 22 & 8 & 15 & reduced \\
\hline 4457 & $0^{g}$ & 10 & 53 & 14 & 16 & reduced \\
\hline 4521 & 2 & 13 & 150 & 110 & 130 & reduced \\
\hline 4427 & 0 & 9 & 69 & 16 & 33 & reduced \\
\hline 4408 & 1 & 12 & 50 & 20 & 35 & reduced \\
\hline 4494 & 2 & 24 & 160 & 61 & 81 & reduced \\
\hline 4455 & 3 & 40 & 520 & 180 & 190 & reduced \\
\hline 4445 & 4 & 27 & 1700 & 480 & 620 & reduced \\
\hline 4469 & $4 \mathrm{~g}$ & 87 & 370 & 160 & 250 & reduced \\
\hline 4411 & 5 & 28 & 190 & 70 & 94 & reduced \\
\hline 4273 & 5 & 2 & 65 & 11 & 20 & reduced \\
\hline 4530 & 6 & 7 & 33 & 10 & 18 & reduced \\
\hline 4514 & 9 & 10 & 290 & 97 & 210 & reduced \\
\hline 4492 & $14 \mathrm{~g}$ & 8 & 77 & 14 & 24 & reduced \\
\hline 4531 & 6 & 4 & 45 & 7 & 10 & abolished \\
\hline 4400 & 6 & 2 & 240 & 6 & 7 & abolished \\
\hline 4499 & $9 \mathrm{~g}$ & 6 & 83 & 9 & 9 & abolished \\
\hline 4414 & 11 & 23 & 1100 & 25 & 28 & abolished \\
\hline 4406 & 11 & 3 & $220^{f}$ & 7 & 7 & abolished \\
\hline 4500 & 13 & 5 & 170 & 5 & 6 & abolished \\
\hline 4506 & 14 & 8 & $140^{f}$ & 8 & 8 & abolished \\
\hline 4474 & 15 & 4 & 150 & 3 & 4 & abolished \\
\hline 4459 & 18 & 8 & $220^{f}$ & 8 & 9 & abolished \\
\hline 4480 & 21 & 2 & $380^{\mathrm{f}}$ & 5 & 5 & abolished \\
\hline 4529 & 23 & 4 & $180^{f}$ & 5 & 5 & abolished \\
\hline 4401 & 30 & 9 & $230^{\mathrm{f}}$ & 7 & 7 & abolished \\
\hline
\end{tabular}

The site of $\operatorname{Tn} 5$ lac insertion is designated by $\Omega$ followed by a number.

a-f See Table 3 legend, and replace $C^{-}$(Table 3) with $B^{-}$(Table 5$)$.

g Expression time, vegetative specific activity, and/or peak developmental specific activity of the wild-type Tn5 lac strain for these insertions may differ from those reported in Table 3 because the wild-type Tn5 lac profile was obtained in parallel with the B- Tn5 lac profile in a separate experiment from the $\mathrm{C}^{-} \mathrm{Tn} 5$ lac experiment reported in Table 3 . For Tn5 lac insertions that also appear in Table 3 but are not marked with a superscript $\mathrm{g}$, the wild-type Tn5 lac, $\mathrm{C}^{-} \mathrm{Tn} 5 \mathrm{lac}$, and $\mathrm{B}^{-} \mathrm{Tn} 5$ lac profiles were all obtained in the same experiment. Time courses for wild-type and $\mathrm{B}^{-}$strains were repeated in two series of experiments for eight lac fusions in the table and were found to be reproducible.

these conditions are apparently less appropriate for B than for A (Kuspa et al. 1986) or C (above). Further studies will be required to optimize conditions for rescue of $B$ mutants.

\section{Discussion}

\section{$A^{+}$and $B^{+}$are functions required earlier in development than $\mathrm{C}^{+}$}

Both $\mathrm{A}^{+}$and $\mathrm{B}^{+}$appear to act in the first few hours of development. $\mathrm{B}^{+}$is required at least partially for expression of all lac fusions tested, but is not required absolutely for expression of any of the fusions until $6 \mathrm{hr}$ of development (Table 5 ). $\mathrm{A}^{+}$is required absolutely for expression of all but three lac fusions tested and these three normally begin expression in the first $5 \mathrm{hr}$ of development (Kuspa et al. 1986). The requirement for $\mathrm{C}^{+}$is clearly separated in time from the early requirements for $\mathrm{A}^{+}$and $\mathrm{B}^{+} . \mathrm{C}^{+}$is not required for expression of any lac fusions that normally begin expression before $6 \mathrm{hr}$ of development (Table 3). Fusion $\Omega 4427$ is interesting in this regard because it does not require $\mathrm{C}^{+}$for $\beta$-galactosidase expression before $6 \mathrm{hr}$ but does require $\mathrm{C}^{+}$for normal expression after $6 \mathrm{hr}$. $\mathrm{C}^{+}$is required at least partially for expression of all Tn5 lac insertions tested that normally begin expression after $6 \mathrm{hr}$ of development and is required absolutely for expression at $11 \mathrm{hr}$ of development and seven other fusions that are expressed of fusion $\Omega 4406$ that normally begins expression after $11 \mathrm{hr}$ (Table 3 ). Thus $\mathrm{A}^{+}$and $\mathrm{B}^{+}$are required several hours earlier than $\mathrm{C}^{+}$during Myxococcus development.

The available data do not order $\mathrm{A}^{+}$relative to $\mathrm{B}^{+}$unambiguously, because both $\mathrm{A}^{+}$and $\mathrm{B}^{+}$appear to be required early for the expression of most lac fusions. However, the fact that $\Omega 4408, \Omega 4455$, and $\Omega 4469$ depend on $\mathrm{B}^{+}$(Table 5), but not on $\mathrm{A}^{+}$(Kuspa et al. 1986), suggests that $\mathrm{B}^{+}$precedes $\mathrm{A}^{+}$.

Based on the expression of several biochemical markers of development, LaRossa et al. (1983) concluded previously that $\mathrm{A}^{-}$mutants appear to be blocked earlier in development than $\mathrm{C}^{-}$and $\mathrm{B}^{-}$mutants. Our results support the conclusion that $\mathrm{A}^{-}$mutants are blocked earlier than the $\mathrm{C}^{-}$mutant, but indicate that a $\mathrm{B}^{-}$mutation, $b s g A 330$, affects developmental gene expression at least as early and most probably earlier than two un- 


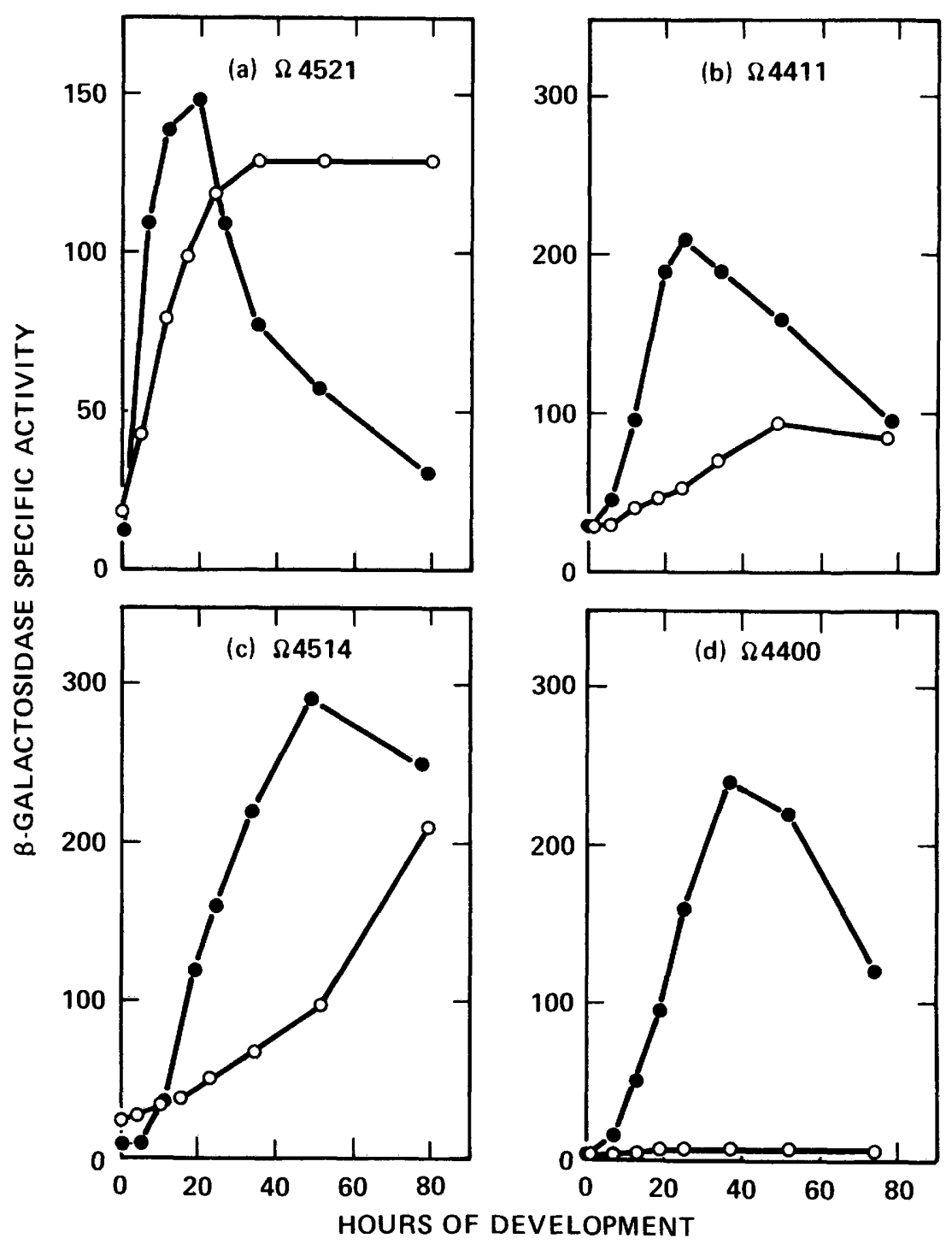

Figure 5. Effects of a $\mathrm{B}^{-}$mutation on expression of lac fusions to four different developmentally regulated transcription units. Wild-type and $\mathrm{B}^{-}$strains containing the same Tn5 lac insertion were constructed, plated for development, and harvested at various times for determination of $\beta$-galactosidase specific activity as described in Materials and methods. Profiles for wild-type $(0)$ and $B^{-}|0|$ strains containing $\operatorname{Tn} 5$ lac insertions $\Omega 4521$ $(a), \Omega 4411(b), \Omega 4514(c)$, and $\Omega 4400(d)$ are shown. linked $\mathrm{A}^{-}$mutations. On grounds of morphology, the $\mathrm{B}^{-}$ mutant arrests development at an earlier stage of aggregation than the $\mathrm{C}^{-}$mutant (Fig. 1). Using bsgA330 but a different set of Tn5 lac insertions and different conditions for development, Gill and Cull (1986) also concluded that $b s g A$ mutants are blocked very early because all five of their lac fusions were completely dependent on B. LaRossa et al. (1983) based their conclusions on the qualitative detection of protein $\mathrm{S}$ and myobacterial hemagglutinin. It is possible that they detected protein $S$ because its expression is reduced but not abolished in a $\mathrm{B}^{-}$ mutant strain as measured by $\beta$-galactosidase from $\operatorname{Tn} 5$ lac $\Omega 4273$ (Table 5). $\Omega 4273$ is an insertion of $\operatorname{Tn} 5$ lac in the protein $S$ gene (Kroos et al. 1986).

\section{$A^{+}, B^{+}$, and $C^{+}$lie on the same dependent pathway}

$\mathrm{A}^{+}, \mathrm{B}^{+}$, and $\mathrm{C}^{+}$are essential steps in Myxococcus development: $\mathrm{A}^{-}, \mathrm{B}^{-}$, and $\mathrm{C}^{-}$mutants fail to sporulate or to complete aggregation, and they alter expression of $\beta$-galactosidase from fusions of $l a c Z$ to developmentally regulated promoters. The fact that $\mathrm{A}^{+}$and $\mathrm{B}^{+}$are required earlier in development than $\mathrm{C}^{+}$is compatible with two general types of regulatory circuits: a dependent pathway in which $\mathrm{A}^{+}$and $\mathrm{B}^{+}$precede $\mathrm{C}^{+}$; or multiple pathways connected to a common timer such that $\mathrm{A}^{+}$ and $\mathrm{B}^{+}$are set to function at an earlier time than $\mathrm{C}^{+}$ (Jarvik and Botstein 1973; Hartwell et al. 1974). The pattern of dependences on $\mathrm{A}^{+}, \mathrm{B}^{+}$, and $\mathrm{C}^{+}$argue against a common timer and for a dependent regulatory pathway. For example, all 11 fusions that depend on $\mathrm{C}^{+}$also depend on $\mathrm{A}^{+}$. All three fusions that are independent of $\mathrm{A}^{+}$ are also independent of $\mathrm{C}^{+}$. A third class, containing five fusions all normally expressed before $6 \mathrm{hr}$ of development, depends on $\mathrm{A}^{+}$but not on $\mathrm{C}^{+}$. In addition, no fusions were found to depend for developmental expression on $\mathrm{C}^{+}$but not on $\mathrm{A}^{+}$. One might have expected to find such fusions if $\mathrm{A}^{+}$and $\mathrm{C}^{+}$were on separate pathways coordinated by a common timer.

The dependence classes for $\mathrm{B}^{+}$and $\mathrm{C}^{+}$are analogous to those for $\mathrm{A}^{+}$and $\mathrm{C}^{+}$. Thus, all 12 fusions that were tested with both $\mathrm{B}^{+}$and $\mathrm{C}^{+}$, and were found to depend at least partially on $\mathrm{C}^{+}$for their expression, also depend at least partially on $\mathrm{B}^{+}$(Tables 3 and 5 ). Ten fusions were found to depend partially on $\mathrm{B}^{+}$but not on $\mathrm{C}^{+}$, and 
all of them normally begin expression before $6 \mathrm{hr}$ of development. No fusions were found to depend on $\mathrm{C}^{+}$but not on $\mathrm{B}^{+}$. Three fusions were found to depend partially on both $\mathrm{B}^{+}$and $\mathrm{C}^{+}(\Omega 4427, \Omega 4514$, and $\Omega 4492)$. In all three cases the degree of dependence appears to be greater on $\mathrm{B}^{+}$than on $\mathrm{C}^{+}$, in the sense that a smaller fraction of maximum $\beta$-galactosidase activity at the time of the wild-type peak was found in $\mathrm{B}^{-}$than in $\mathrm{C}^{-}$ (compare Tables 3 and 5). Since $\mathrm{B}^{+}$is required earlier than $\mathrm{C}^{+}$during development (see above) and since each of 22 lac fusions showed greater dependence on $\mathrm{B}^{+}$than on $\mathrm{C}^{+}$, our results argue that $\mathrm{B}^{+}$functions before $\mathrm{C}^{+}$on the same dependent developmental pathway.

\section{Branches in the regulatory pathway}

Although $\mathrm{A}^{+}, \mathrm{B}^{+}$, and $\mathrm{C}^{+}$appear to function on the same dependent pathway during Myxococcus development, the observation that certain lac fusion strains that begin to express $\beta$-galactosidase at about the same time can differ in their dependence on $\mathrm{A}^{+}, \mathrm{B}^{+}$, and/or $\mathrm{C}^{+}$suggests that the pathway is branched. In the diagram of Figure 6, each lac fusion is positioned along the $x$ axis according to the time that it begins $\beta$-galactosidase expression in an $\mathrm{A}^{+} \mathrm{B}^{+} \mathrm{C}^{+}$strain. Position on the $y$ axis for each fusion represents its level of dependence on $\mathrm{A}^{+}, \mathrm{B}^{+}$, and $\mathrm{C}^{+}$, as measured by $\beta$-galactosidase expression during development. A higher vertical position implies dependence on more factors or an increased dependence on the same factor. For example, Tn5 lac $\Omega 4514$ normally begins expression at $9 \mathrm{hr}$ of development; its $x$ coordinate is $9 \mathrm{hr}$. $\beta$-Galactosidase expression from $\Omega 4514$ depends partially on both $\mathrm{B}^{+}$and $\mathrm{C}^{+}$/since $\beta$-galactosidase expression was reduced in the $\mathrm{B}^{-}$and $\mathrm{C}^{-}$ mutants) and depends absolutely on $\mathrm{A}^{+}$for its expression (since no expression was seen in $\mathrm{A}^{-}$mutants), therefore its $y$ coordinate is the third level. Tn5 lac $\Omega 4406$ is placed to the right of $\Omega 4514$ because $\Omega 4406$ normally begins expression at $11 \mathrm{hr}$ of development, and on the top level because it depends absolutely on $\mathrm{A}^{+}$, $\mathrm{B}^{+}$, and $\mathrm{C}^{+}$for its expression. The position of some $\operatorname{Tn} 5$ lac insertions in the diagram is tentative because some combinations have not yet been tested, as indicated in the legend to Figure 6.

Figure 6 can be interpreted as a partial map of the regulatory pathway that controls Myxococcus development. In all, 22 of 31 lac fusions lie on the uppermost line in Figure 6, which follows a step-wise course; we will refer to this line as the "main" pathway. The main pathway leads to sporulation since nearly all of the fusions on this pathway that begin to increase $\beta$-galactosidase expression after $10 \mathrm{hr}$ of development continue to increase $\beta$-galactosidase specific activity in spores (i.e., in sonication-resistant cells). Expression of $\beta$-galactosidase from fusions on the main pathway is controlled by $\mathrm{A}^{+}, \mathrm{B}^{+}$, and/or $\mathrm{C}^{+}$as shown. However, several sets of fusions that are expressed at about the same developmental time can nevertheless depend on $\mathrm{A}^{+}, \mathrm{B}^{+}$, and $\mathrm{C}^{+}$ to different extents. For example, expression of $\beta$-galactosidase from both Tn5 lac $\Omega 4411$ and Tn5 lac $\Omega 4469$ begins at about $5 \mathrm{hr}$ of development, but expression from Tn5 lac $\Omega 4411$ (on the main pathway) requires $\mathrm{A}^{+}$ whereas expression from $\operatorname{Tn} 5$ lac $\Omega 4469$ does not require $\mathrm{A}^{+}$. This and similar cases can be accommodated by adding three branches below the main pathway as shown in Figure 6. A single pathway starts development since all fusions depend to some extent on $\mathrm{B}^{+}$for their expression. The three branches diverge at about 0,6 , and $10 \mathrm{hr}$ from the main pathway. The 0 - $\mathrm{hr}$ branch is added because fusions $\Omega 4408, \Omega 4455$, and $\Omega 4469$ do not require $\mathrm{A}^{+}$for their expression, whereas other fusions on the main pathway expressed at almost the same time do require $\mathrm{A}^{+}$(Kuspa et al. 1986). The 6- and 10-hr branches in Figure 6 are introduced because some fusions display reduced $\beta$-galactosidase expression in the $\mathrm{B}^{-}$and/or $\mathrm{C}^{-}$ mutant whereas other fusions that normally begin $\beta$-galactosidase expression at the same time of development display no expression in the $\mathrm{B}^{-}$and/or $\mathrm{C}^{-}$mutant.

Additional experiments are required to elucidate the mechanism by which $\mathrm{B}^{-}$and $\mathrm{C}^{-}$mutations reduce without abolishing the expression of certain developmentally regulated genes. One possibility is that the genes whose expression is reduced have two promoters, one completely dependent, the other completely independent. Another possibility is that the $\mathrm{B}^{-}$and $\mathrm{C}^{-} \mathrm{mu}-$ tants make lowered amounts or altered forms of an intercellular signal. Alternatively, cells may have secondary mechanisms that allow partial gene expression in the absence of a cell-cell interaction.

The fact that there exist mutants of Myxococcus that aggregate but do not sporulate, and other mutants that sporulate but do not aggregate, has suggested that aggregation and sporulation lie on separate branches of a developmental pathway (Morrison and Zusman 1979; Shimkets 1987). Aggregation of wild-type cells results in formation of translucent mounds by $12 \mathrm{hr}$ of development (Fig. 1). The $\mathrm{A}^{-}, \mathrm{B}^{-}$, and $\mathrm{C}^{-}$mutants, which were selected for inability to sporulate, also are found to have defects in aggregation. This would suggest either that sporulation depends on aggregation, or that both depend on a common prior function(s). In particular, $\mathrm{A}^{-}$and $\mathrm{B}^{-}$ mutants show little aggregation; $\mathrm{C}^{-}$mutants do construct mounds, but these have abnormal morphology and are unstable. These mutant phenotypes show that aggregation is regulated, either directly or indirectly, by $\mathrm{A}^{+}, \mathrm{B}^{+}$, and $\mathrm{C}^{+}$. However, lacking knowledge of individual aggregation functions, and their degree of dependence on $\mathrm{A}^{+}, \mathrm{B}^{+}$, and $\mathrm{C}^{+}$, it is not yet possible to place them on (or off) the diagram shown in Figure 6.

\section{Extracellular rescue of the $\mathrm{C}^{-}$defect}

The earliest effects of a $\mathrm{C}^{-}$mutation on developmentally regulated $\beta$-galactosidase expression from lac fusions were observed between 6 and $12 \mathrm{hr}$. During this period, cells are normally aggregating into compact mounds. Between these mounds, cells accumulate in low parallel ridges (ripples). $\mathrm{C}^{-}$mutants fail to form compact mounds or ripples by $12 \mathrm{hr}$ of development, although they do form larger, looser and less regular mounds by $18-24 \mathrm{hr}$ of development. Thus, morphological defects are manifest in $\mathrm{C}^{-}$mutants between 6 and $12 \mathrm{hr}$ (Fig. 1), the same time that gene expression defects are first evident. When wild-type cells are mixed with 


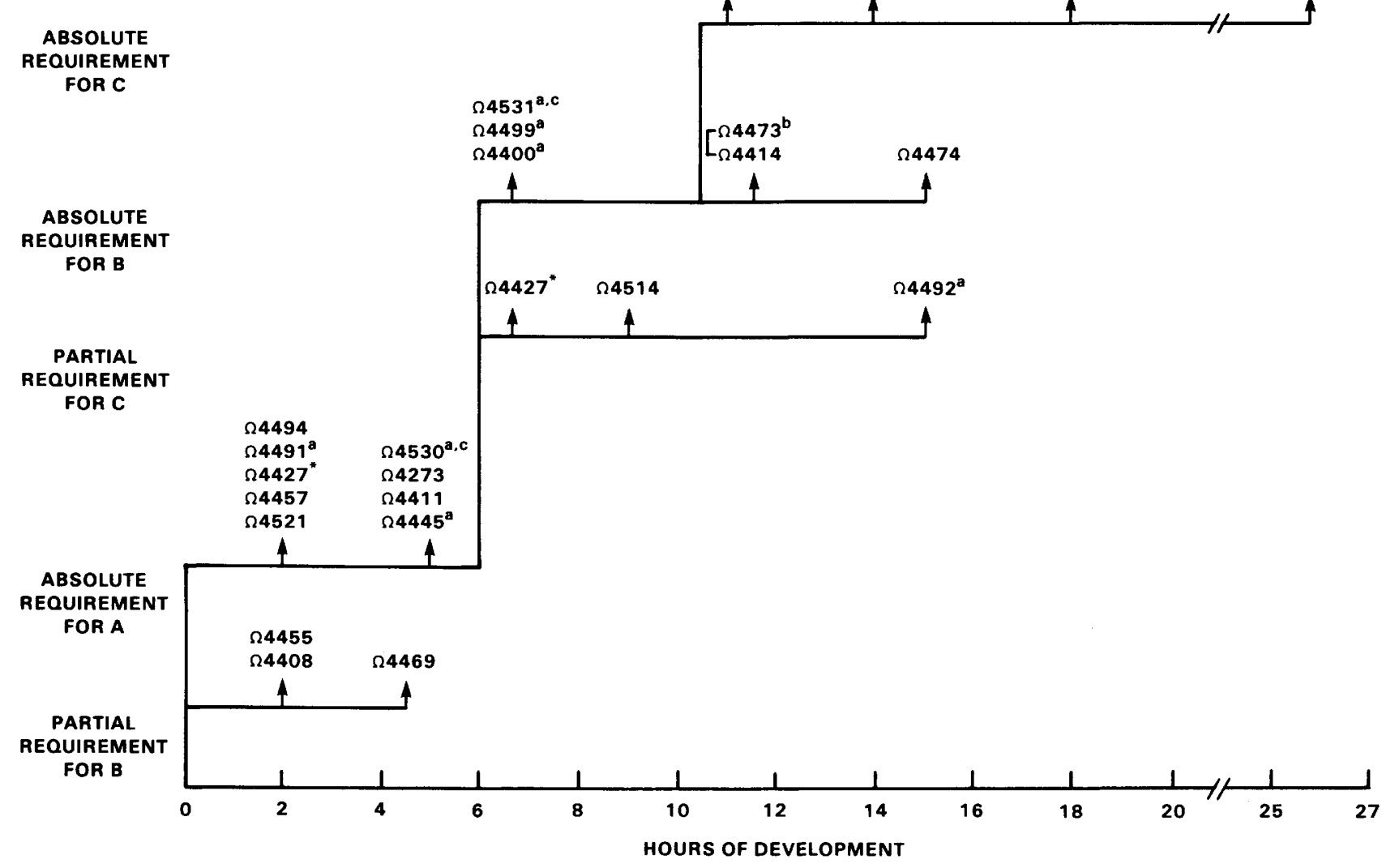

Figure 6. Dependence of gene expression on $\mathrm{A}^{+}, \mathrm{B}^{+}$, and $\mathrm{C}^{+}$, and on time. The diagram summarizes the effects of two different $\mathrm{A}^{-}$ mutations (Kuspa et al. 1986), a $\mathrm{C}^{-}$mutation, and a $\mathrm{B}^{-}$mutation on $\beta$-galactosidase expression from the same set of Tn5 lac insertions. The Tn5 lac insertions are placed along the $x$ axis according to the point of developmental time at which they normally begin expression in wild-type cells. Tn5 lac insertions with similar expression times are grouped above arrows that depict the average expression time of the group. Tn5 lac insertions are placed along the $y$ axis according to their dependence on $\mathrm{A}^{+}, \mathrm{B}^{+}$, and $\mathrm{C}^{+}$. For example, Tn5 lac insertions that displayed reduced expression in the $\mathrm{B}^{-}$mutant (Table 5) are placed above the level "partial requirement for B" in the diagram, whereas Tn5 lac insertions that failed to be expressed in the $\mathrm{B}^{-}$mutant are placed above the level

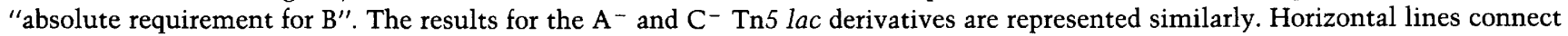
Tn5 lac insertion with the same dependence pattern. Vertical lines mark the time at which requirements for $\mathrm{A}^{+}, \mathrm{B}^{+}$, and $\mathrm{C}^{+}$are first manifest and they indicate the cumulative nature of the dependences. Brackets ([) connect Tn5 lac insertions with related restriction maps (Kroos et al. 1986). Superscript a, b, or c associated with an $\Omega$ number indicates the Tn5 lac insertion has not yet been tested in the $\mathrm{A}^{-}$mutants, the $\mathrm{B}^{-}$mutant, or the $\mathrm{C}^{-}$mutant, respectively. Tn 5 lac $\Omega 4427$ is starred because it exhibits no requirement for $\mathrm{C}^{+}$ before $6 \mathrm{hr}$ of development, but a partial requirement for $\mathrm{C}^{+}$after $6 \mathrm{hr}$ (Fig. 3d), and so it appears twice in the diagram.

$\mathrm{C}^{-}$mutant cells in equal proportion, mounds and ripples that are normal in appearance form by $12 \mathrm{hr}$. We do not know the extent to which $\mathrm{C}^{-}$mutants participate in mound formation and rippling in the mixture with wild-type cells. However, we do know that sporulation of $\mathrm{C}^{-}$mutants in the mixture is restored to wild-type levels (Table 2). Furthermore, an approximately normal pattern of developmental gene expression from six lac fusions in the $\mathrm{C}^{-}$mutant background was restored in the mixture with wild-type cells (Table 4). Among the lac fusions rescued are those that are normally expressed at $6 \mathrm{hr}$ of development in $\mathrm{C}^{+}$strains, when the $\mathrm{C}^{-}$defect is first manifest (Fig. 4a). These data argue that the wild-type cells rescue by providing an intercellular signal at about $6-12 \mathrm{hr}$ of development that is missing in the $\mathrm{C}^{-}$mutants. The rescue of $\beta$-galactosidase expression from a lac fusion in a $\mathrm{C}^{-}$mutant provides a bioassay to explore the molecular basis of the observed extracellular complementation.

\section{Materials and methods}

Construction of $C^{-}$and $B^{-} \operatorname{Tn} 5$ lac derivatives

The $\mathrm{C}^{-}$and $\mathrm{B}^{-}$mutations used to construct $\mathrm{Tn} 5$ lac derivatives were each produced by insertion of a tetracycline resistance $\left(\mathrm{Tc}^{\mathrm{r}}\right.$ ) marker. The $\mathrm{Tc}^{\mathrm{r}}$ marker gene originated from $\mathrm{Tn} 10$ (Foster et al. 1981) and confers on $M$. xanthus resistance to $15 \mu \mathrm{g} / \mathrm{ml}$ oxytetracycline (Avery and Kaiser 1983). M. xanthus strain LS523 contains Tn5-132 RLS205 inserted in the csg locus (Shimkets and Asher 1987). M. xanthus strain M380 contains 
the $\mathrm{Tc}^{\mathrm{r}}$-encoding $B g I I I$ fragment from $\mathrm{Tn} 10$ inserted in a unique $B g I I I$ restriction site in the $b s g A$ locus, which was called $s s b A$ (Gill and Cull 1986) and renamed bsgA. Plate stocks of myxophage Mx8 clp2 (Martin et al. 1978) were grown on donor strains LS523 (csg-205) and M380 (bsgA330) and used to transduce $M$. xanthus strain DK101 (sglA1, Hodgkin and Kaiser 1979) to $\mathrm{Tc}^{\mathrm{r}}$ as described (Avery and Kaiser 1983). This transduction replaced the resident $\mathrm{C}^{+}$or $\mathrm{B}^{+}$gene with a disrupted allele, and gave strains DK5216 (containing $\mathrm{C}^{-}$insertion csg-205) and DK5217 (containing $\mathrm{B}^{-}$insertion bsgA330). This initial transduction of the $\mathrm{C}^{-}$and $\mathrm{B}^{-}$mutations into DK101 was employed because we were then able to prepare higher titer liquid stocks of Mx8 clp2 on the DK101 derivatives than on the original $\mathrm{sglA1}{ }^{+}$strains LS523 and M380, facilitating transduction of the $\mathrm{C}^{-}$and $\mathrm{B}^{-}$mutations into a large number of $\mathrm{Tn} 5$ lac insertion-containing strains described by Kroos et al. (1986). Liquid stocks of $\mathrm{Mx} 8 \mathrm{clp} 2$ were prepared by infecting cells growing exponentially in CTT liquid medium (Hodgkin and Kaiser 1977) at a density of $2 \times 10^{8}$ cells $/ \mathrm{ml}$ with a phage multiplicity of 0.01 and incubating at $32^{\circ} \mathrm{C}$ for $24-36 \mathrm{hr}$ with shaking (L. Avery, unpubl.). All Tn5 lac insertion strains that were used as recipients either arose from P1 : : Tn5 lac infection of $M$. xanthus strain DK1622 (wild type) or the Tn5 lac insertion was transduced from the $M$. xanthus strain in which it was originally isolated into DK1622 using Mx8 clp2 and selecting for kanamycin-resistance $\left(\mathrm{Km}^{\mathrm{r}}\right)$ (Kroos et al. 1986). The $\mathrm{Tc}^{\mathrm{r}}$ of transductants of the lac fusion strains was verified by transfer to CTT agar plates (Hodgkin and Kaiser 1977) containing $12.5 \mu \mathrm{g} / \mathrm{ml}$ oxytetracycline. For each strain constructed (Table 1), 10-15 $\mathrm{Tc}^{\mathrm{r}}$ transductants were transferred to CTT agar plates containing $40 \mu \mathrm{g} / \mathrm{ml}$ kanamycin sulfate to test for retention of the $\mathrm{Tn} 5$ lac insertion. All $\mathrm{Tc}^{\mathrm{x}}$ transductants were also $\mathrm{Km}^{\mathrm{r}}$ for all strains constructed. Thus, no genetic linkage (i.e., $<7-10 \%$ ) was observed between any of the $\operatorname{Tn} 5$ lac insertions and the $\mathrm{Tc}^{\mathrm{r}}$ markers in csg-205 and bsgA330 in the crosses that were performed (see Table 1). The $\mathrm{Tc}^{\mathrm{r}} \mathrm{Km}^{\mathrm{r}}$ transductants were all transferred to CTT agar plates containing $40 \mu \mathrm{g} / \mathrm{ml} \mathrm{5-}$ bromo-4-chloro-3-indolyl- $\beta$-D-galactoside (X-Gal) and TPM [10 $\mathrm{mM}$ Tris $\left.\mathrm{HCl}(\mathrm{pH} 7.5), 1 \mathrm{mM} \mathrm{KH} \mathrm{PO}_{4} \cdot \mathrm{K}_{2} \mathrm{HPO}_{4}, 8 \mathrm{mM} \mathrm{MgSO}{ }_{4}\right]$ agar plates containing $20 \mu \mathrm{g} / \mathrm{ml} \mathrm{X}-\mathrm{Gal}$ and examined after 1, 2, and 3 days at $32^{\circ} \mathrm{C}$. For each cross, one transductant which displayed colony color (on the X-Gal plates) typical of the majority of transductants from the cross was chosen for further study and given the strain number shown in Table 1. As described previously (Kuspa et al. 1986), in such crosses transductants with aberrant $\beta$-galactosidase expression arise at a low frequency $(0.2 \%)$, possibly due to mutations in lac $Z$ or transposition of Tn5 lac to a different chromosomal site, and the screen for colony color eliminates such aberrant transductants.

Since the $\mathrm{B}^{-}$mutation is caused by insertion of a $\mathrm{Tc}^{\mathrm{r}}$ marker, all $\mathrm{Tc}^{\mathrm{r}}$ transductants are expected to exhibit the mutant phenotype, and all $\mathrm{B}^{-}$Tn 5 lac derivatives listed in Table 1 did display the expected developmental defect when plated on TPM agar as described below. In the case of the $\mathrm{C}^{-}$mutation, since the $\mathrm{Tc}^{\mathrm{r}}$ marker is encoded in a transposon ( $\operatorname{Tn} 5-132 \Omega 205$ ) inserted in the csg locus, $\mathrm{Tc}^{\mathrm{r}}$ transductants could in principle arise from Tn5-132 which had transposed to new sites either in the donor strain (i.e., before the transduction) or in the recipient strain (i.e., during the transduction). However, the frequency of transposition of $\operatorname{Tn} 5$ (or related transposons, like Tn5-132) is low compared with the frequency of homologous recombination in M. xanthus (Kuner and Kaiser 1981) and all the $\mathrm{C}^{-}$Tn5 lac derivatives listed in Table 1 displayed their expected developmental defects when plated on TPM agar as described below. As an additional verification of genotype, we showed that $\mathrm{C}^{-}$ strains LS523 and DK5216, as well as three $C^{-}$Tn5 lac deriva- tives (DK5250, DK5248, and DK5251), contain Tn5-132 at the expected site, $\Omega 205$, by isolating DNA from each strain (Avery and Kaiser 1983), digesting it with EcoRI, and showing that for each strain two fragments ( 3.8 and $27 \mathrm{~kb}$ in length) are detected by nick-translated (Davis et al. 1980) ColE1 : : Tn5-132 DNA in a Southern (Southern 1975) blot filter hybridization experiment (data not shown). Each of the $\mathrm{C}^{-} \mathrm{Tn} 5$ lac derivatives possessed, in addition, a third hybridizable fragment due to the presence of Tn5 lac.

\section{Quantitation of lysis and sporulation}

To determine the number of rod-shaped cells and/or spores at different times during development, strains were grown, sedimented, and resuspended as described above. Cells were plated for development and harvested for quantitation of rods and spores according to the following procedure developed by $\mathrm{K}$. Mayo (pers. comm.). One 20- $\mu$ l aliquot of cells was placed on the surface of a $1.5-\mathrm{ml}$ TPM agar mini-plate formed in the well of a 24-well tissue culture plate (Falcon) for each developmental time point. After incubation at $32^{\circ} \mathrm{C}$, each sample was harvested by adding $0.5 \mathrm{ml}$ of TPM buffer to the well, dislodging the cell mat with a bent loop, transferring the sample with a pasteur pipette to a $1.5-\mathrm{ml}$ tube containing an additional $0.5 \mathrm{ml}$ of TPM buffer, and washing the well with half of the 1-ml sample to ensure maximal recovery of the cell mat.

To quantitate both rods and spores in the sample, glutaraldehyde $(2 \% \mathrm{vol} / \mathrm{vol})$ was added to stabilize rod-shaped cells and render them sonication resistant. Samples were exposed to glutaraldehyde for at least $24 \mathrm{hr}$ at $4^{\circ} \mathrm{C}$ prior to sonication for 30 sec. Control experiments showed that this sonication treatment did not disrupt glutaraldehyde-fixed, rod-shaped cells but was sufficient to release them from the cell mat. The sonication disaggregated clumps of spores and permitted counting of rods and spores in a Petroff-Hausser chamber using phase-contrast microscopy.

To quantitate spores that are both sonication and heat resistant, the sample was harvested as described above after 3 days at $32^{\circ} \mathrm{C}$. Samples were incubated for $2 \mathrm{hr}$ at $50^{\circ} \mathrm{C}$ and then sonicated for $45 \mathrm{sec}$. The heat and sonication treatments kill rodshaped cells. Appropriate dilutions of the spore-containing samples were made in TPM buffer and mixed with $2.5 \mathrm{ml}$ of CTT soft agar $(0.7 \%)$ for plating on CTT agar $(1.5 \%)$ plates. Plates were incubated for 6 days at $32^{\circ} \mathrm{C}$ to allow spores to germinate and form colonies which were then counted.

\section{Measurement of developmental $\beta$-galactosidase expression}

Expression of $\beta$-galactosidase from Tn5 lac insertion-containing $M$. xanthus strains was quantitated as described previously (Kroos et al. 1986). Briefly, cells growing exponentially in CTT liquid medium were sedimented and resuspended in TPM buffer at a density of $5 \times 10^{9}$ cells $/ \mathrm{ml}$. A $0.1-\mathrm{ml}$ aliquot was added to $0.3 \mathrm{ml}$ of TPM and was stored at $-20^{\circ} \mathrm{C}$ for later determination of $\beta$-galactosidase activity in growing cells $(t=0$ sample). For development, $20-\mu l$ aliquots were spotted on TPM agar plates, the spots were allowed to dry for $1 \mathrm{hr}$ at room temperature, then plates were incubated at $32^{\circ} \mathrm{C}$. At various times cells were scraped from the agar into TPM buffer and stored at $-20^{\circ} \mathrm{C}$ until all samples were collected. The specific activity of $\beta$-galactosidase ( 1 unit $=1$ nmole $o$-nitrophenol produced per minute per milligram protein) in each sample was determined after sonication/rod-shaped cells but not spores are disrupted) or, in the cases noted in the text and tables, after sonication with $75-$ to $150-\mu \mathrm{m}$ acid-washed glass beads (Sigma) to disrupt spores as described (Kroos et al. 1986). 


\section{Extracellular complementation of $\beta$-galactosidase expression}

To determine whether wild-type (DK1622) cells could restore $\beta$-galactosidase expression from $\mathrm{C}^{-}$or $\mathrm{B}^{-} \operatorname{Tn} 5$ lac derivatives during codevelopment, the strains were grown, sedimented, and resuspended as described above. Equal volumes of the two cell types were mixed and $20-\mu \mathrm{l}$ aliquots of the mixture were spotted for development on TPM agar plates. Samples were harvested and their $\beta$-galactosidase-specific activity was determined as described above. Since half the cells in the mixtures do not contribute $\beta$-galactosidase activity but do contribute to the total protein concentration of the sample, the total protein concentration was divided by 2 before calculating a specific activity.

\section{Extracellular complementation of sporulation}

To test whether codevelopment with wild-type cells could rescue sporulation of the $\mathrm{C}^{-}$and $\mathrm{B}^{-}$mutants, mixtures were made as described above and $20-\mu l$ aliquots of the mixture were spotted on TPM agar in 24-well tissue culture plates. Samples were harvested after 3 days of incubation at $32^{\circ} \mathrm{C}$, heated for 2 $\mathrm{hr}$ at $50^{\circ} \mathrm{C}$, sonicated for $45 \mathrm{sec}$, and plated as described above for the quantitation of heat- and sonication-resistant viable spores.

The developmentally competent strain (DK4696, K. Mayo, pers. comm.) employed in these extracellular complementation tests carries the red-2 mutation which gives colonies of DK4696 a red color that is easily distinguished from the normal yellow color of most $M$. xanthus strains. The red strain DK4696 is $\mathrm{B}^{+}$and $\mathrm{C}^{+}$and develops normally. Use of a red strain as the wild-type partner in an extracellular complementation test with a yellow mutant strain reveals whether a colony has arisen from a wild-type spore (red colony) or a mutant spore (yellow colony). However, both the red strain and the yellow strains give rise to tan colonies by phase variation, which cannot be distinguished by their color. For experiments in which the yellow strain was kanamycin sensitive $\left(\mathrm{Km}^{\mathrm{s}}\right)$, the origin of the tan colonies could be inferred by transferring them to CTT agar plates containing $40 \mu \mathrm{g} / \mathrm{ml}$ kanamycin sulfate and incubating 3 days at $32^{\circ} \mathrm{C}$. For experiments in which the yellow strain was kanamycin resistant, because it contains a Tn5 lac insertion, the origin of the tan colonies could be inferred by spraying them with a $1 \mathrm{mg} / \mathrm{ml}$ solution of 4-methylumbelliferyl- $\beta$-D-galactosidase (MUG) in dimethyl sulfoxide. Tan colonies that originated from the red strain fail to fluoresce under $366 \mathrm{~nm}$ UV illumination after being sprayed with MUG, while those that originated from yellow Tn5 lac-containing strains do fluoresce, since all $M$. xanthus strains that contain Tn5 lac express at least a low level of $\beta$-galactosidase during growth (Kroos et al. 1986). The use of MUG was suggested by P. Youngman (pers. comm.), and we find that it is more sensitive than X-Gal in plates for the detection of low levels of $\beta$-galactosidase expression in tan colonies of Myxococcus. The MUG method was found to be less sensitive for yellow colonies than for tan colonies.

\section{Acknowledgments}

We thank Ron Gill, Larry Shimkets, and Kristen Mayo for providing strains and Adam Kuspa for helpful discussions. This investigation was supported by grants GM-23441 and AGO-2908 from the National Institutes of Health (NIH). Stipend support for L. Kroos was provided by NIH Training Grant GM-07599.

\section{References}

Avery, L. and D. Kaiser. 1983. In situ transposon replacement and isolation of a spontaneous tandem genetic duplication. Mol. Gen. Genet. 191: 99-109.

Burchard, R.P., A.C. Burchard, and J.H. Parish. 1977. Pigmentation phenotype instability in Myxococcus xanthus. Canad. J. Microbiol. 23: 1657-1662.

Davis, R.W., D. Botstein, and J.R. Roth. 1980. A manual for genetic engineering: Advanced bacterial genetics. Cold Spring Harbor Laboratory, Cold Spring Harbor, New York. $251 \mathrm{pp}$.

Foster, T.J., M.A. Davis, D.E. Roberts, K. Takeshita, and N. Kleckner. 1981. Genetic organization of transposon Tn10. Cell 23: $201-213$.

Gill, R. and M. Cull. 1986. Control of developmental gene expression by cell-to-cell interactions in Myxococcus xanthus. J. Bacteriol. 168: 341-347.

Hagen, D.C., A.P. Bretscher, and D. Kaiser. 1978. Synergism between morphogenetic mutants of Myxococcus xanthus. Dev. Biol. 64: 284-296.

Hartwell, L.H., J. Culotti, J.R. Pringle, and B.J. Reid. 1974. Genetic control of the cell division cycle in yeast. Science 183: $46-51$.

Hodgkin, J. and D. Kaiser. 1977. Cell-to-cell stimulation of movement in nonmotile mutants of Myxococcus. Proc. Natl. Acad. Sci. 74: 2938-2942.

-1979. Genetics of gliding motility in Myxococcus xanthus (Myxobacterales): Two gene systems control movement. Mol. Gen. Genet. 171: 177-191.

Janssen, G. and M. Dworkin. 1985. Cell-cell interactions in developmental lysis of Myxococcus xanthus. Dev. Biol. 112: $194-202$.

Jarvik, J. and D. Botstein. 1973. A genetic method for determining the order of events in a biological pathway. Proc. Natl. Acad. Sci. 70: 2046-2050.

Kaiser, D., L. Kroos, and A. Kuspa. 1985. Cell interactions govern the temporal pattern of Myxococcus development. Cold Spring Harbor Symp. Quant. Biol. 50: 823-830.

Kroos, L., A. Kuspa, and D. Kaiser. 1986. A global analysis of developmentally regulated genes in Myxococcus xanthus. Dev. Biol. 117: 252-266.

Kroos, L. and D. Kaiser. 1984. Construction of Tn5 lac, a transposon that fuses $1 a c Z$ expression to exogenous promoters, and its introduction into Myxococcus xanthus. Proc. Natl. Acad. Sci. 81:5816-5820.

Kuner, J. 1980. "Developmental genetics of Myxococcus xanthus." Ph.D. thesis. Department of Biology, Stanford University.

Kuner, J. and D. Kaiser. 1981. Introduction of transposon Tn5 into Myxococcus for analysis of developmental and other nonselectable mutants. Proc. Nat1. Acad. Sci. 78: 425-429.

Kuspa, A., L. Kroos, and D. Kaiser. 1986. Intercellular signalling is required for developmental gene expression in Myxococcus xanthus. Dev. Biol. 117: 267-276.

LaRossa, R., J. Kuner, D. Hagen, C. Manoil, and D. Kaiser. 1983. Developmental cell interactions of Myxococcus xanthus: Analysis of mutants. J. Bacteriol. 153: 1394-1404.

Martin, S., E. Sodergren, T. Masuda, and D. Kaiser. 1978. Systematic isolation of transducing phages for Myxococcus xanthus. Virology 88: 44-53.

Morrison, C. and D. Zusman. 1979. Myxococcus xanthus mutants with temperature-sensitive, stage-specific defects: Evidence for independent pathways in development. $/$. Bacteriol. 140: 1036-1042.

Rosenberg, E. 1984: Myxobacteria development and cell interactions. Springer-Verlag, New York. 
Shimkets, L.J. 1987. Control of morphogenesis in myxobacteria. Crit. Rev. Microbiol. 14: 195-227.

Shimkets, L.J. and M. Dworkin. 1981. Excreted adenosine is a cell density signal for the initiation of fruiting body formation in Myxococcus xanthus. Dev. Biol. 84: 51-60.

Shimkets, L. and D. Kaiser. 1982. Induction of coordinated movement of Myxococcus xanthus cells. I. Bacteriol. 152:451-461.

Shimkets, L.J., R.E Gill, and D. Kaiser. 1983. Developmental cell interactions in Myxococcus xanthus and the spoC locus. Proc. Natl. Acad. Sci. 80: 1406-1410.

Shimkets, L.J. and S.J. Asher. 1987. Use of recombination techniques to examine the structure of the csg locus of $M y x o-$ coccus xanthus. Mol. Gen. Genet. (in press).

Southern, E.M. 1975. Detection of specific sequences among DNA fragments separated by gel electrophoresis. $J$. Mol. Biol. 98: 503-517.

Wireman, J.W. and M. Dworkin. 1975. Morphogenesis and developmental interactions in myxobacteria. Science 189:516-522. 


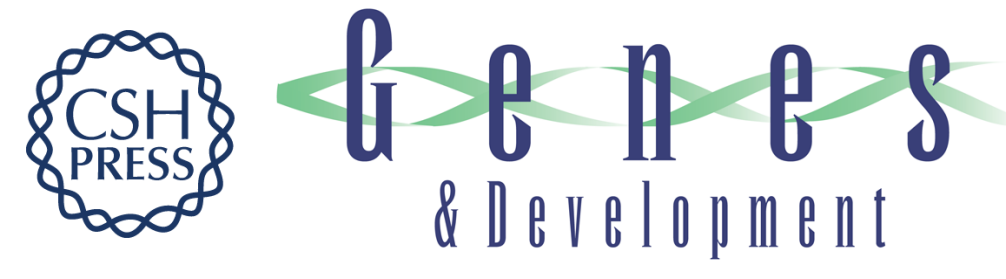

\section{Expression of many developmentally regulated genes in Myxococcus depends on a sequence of cell interactions.}

L Kroos and D Kaiser

Genes Dev. 1987, 1:

Access the most recent version at doi:10.1101/gad.1.8.840

References This article cites 24 articles, 12 of which can be accessed free at: http://genesdev.cshlp.org/content/1/8/840.full.html\#ref-list-1

License

Email Alerting

Receive free email alerts when new articles cite this article - sign up in the box at the top Service right corner of the article or click here.

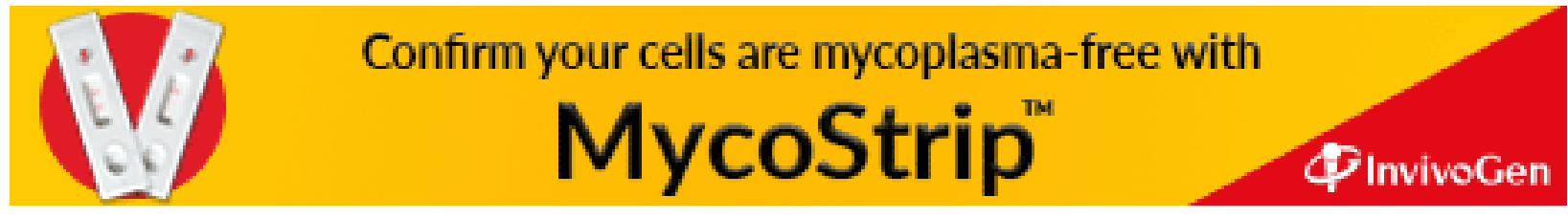

